\title{
A chloride conductance exhibiting bicarbonate conductivity in renal inner medullary collecting duct cells
}

\author{
Juan J. Bolívar, César O. Lara-Figueroa, Ramón H. Martínez-Mayorquin, Florencio Monroy- \\ Romero and Gabina Arenas
}

Department of Physiology, Faculty of Medicine, National Autonomous University of Mexico, Mexico City, Mexico

\begin{abstract}
The anion conductance in primary cultures of rat inner medullary collecting duct cells was studied using perforated-patch whole-cell clamp technique. Depolarizations above $0 \mathrm{mV}$ induced an outward anionic current with a time-dependent activation $\left(\mathrm{I}_{\mathrm{ovt}}\right)$ exhibiting a similar conductivity to $\mathrm{Cl}^{-}$and $\mathrm{HCO}_{3}{ }^{-}$. $\mathrm{I}_{\text {ovt }}$ showed half-maximal activation around $32 \mathrm{mV}$ with a slope factor of $23 \mathrm{mV}$, and showed a voltage-dependent activation time course that was well fitted by a sum of two exponential functions. $\mathrm{I}_{\text {ovt }}$ was potentiated when external $\mathrm{pH}$ values or external $\mathrm{Ca}^{2+}$ concentration was increased and was blocked by external DIDS, DPC and furosemide. These characteristics of $\mathrm{I}_{\mathrm{ovt}}$ resemble that of the $\mathrm{ClC}-\mathrm{K} 1$ channels-mediated currents; however, anion substitution studies showed that $\mathrm{I}_{\mathrm{ovt}}$ exhibits a $\mathrm{Br}^{-}>\mathrm{Cl}^{-}>\mathrm{I}^{-}>\mathrm{NO}_{3}{ }^{-}$conductivity sequence, different from that observed in the $\mathrm{ClC}-\mathrm{K} 1$ channels-mediated conductance. We suggest that, in inner medullary collecting duct cells, $\mathrm{ClC}-\mathrm{K}$ channels of an unidentified type give rise to this $\mathrm{Cl}^{-}$and $\mathrm{HCO}_{3}{ }^{-}$conductance. This is the first study of a channel-mediated $\mathrm{HCO}_{3}{ }^{-}$current in kidney tubular cells.
\end{abstract}

Key words: Kidney - Anion channel - Bicarbonate transport $-\mathrm{Cl}^{-}$current - IMCD

\section{Introduction}

Two decades ago, studies performed on rat and hamster perfused isolated inner medullary collecting ducts (IMCD) reported the presence of a bicarbonate conductance at the basolateral membrane of IMCD cells (Stanton 1989; Imai and Yoshitomi 1990). Neither any other anionic conductance at this membrane nor any anionic conductance at the apical membrane was observed in those studies. Since these earlier reports, some studies performed on IMCD cells in primary culture reported the presence of a cystic fibrosis transmembrane regulator (CFTR) chloride conductance and of a $\mathrm{Ca}^{2+}$-activated chloride $(\mathrm{CaC})$ conductance, probably located at the apical membrane of this cells (Husted et al. 1995; Boese et al. 2004). However, no study has attempted to investigate the nature of the basolateral bicarbonate conductance mentioned above.

Correspondence to: Juan J. Bolívar, Departamento de Fisiología, Facultad de Medicina, Universidad Nacional Autónoma de México, Mexico City DF, 04510, Mexico

E-mail: jjboliv@unam.mx jumedfis@hotmail.com
When explored, bicarbonate conductances have been shown to be mediated by chloride channels. This is the case of the choroid plexus epithelium, where a not yet identified apical $\mathrm{Cl}^{-}$channel mediates a $\mathrm{HCO}_{3}{ }^{-}$flux (Kibble et al. 1996); similarly, in airway, gallbladder, and pancreatic duct epithelia an apical CFTR $\mathrm{Cl}^{-}$channel mediates bicarbonate secretion (Illek et al. 1997; Moser et al. 2007; Ishiguro et al. 2009). Hence, it is quite plausible that, at the basolateral membrane of IMCD cells, a not previously described $\mathrm{Cl}^{-}$channel mediates the observed bicarbonate conductance.

With the aim of determining if $\mathrm{Cl}^{-}$conductance exhibiting $\mathrm{HCO}_{3}{ }^{-}$conductivity is present at the membranes of IMCD cells in primary culture, we explored the anionic conductance in these cells, using the perforated-patch whole cell clamp technique. We observed a time-dependent outward rectifying anion conductance $\left(\mathrm{I}_{\text {ovt }}\right)$ exhibiting a similar conductivity to $\mathrm{HCO}_{3}{ }^{-}$than to $\mathrm{Cl}^{-}$. Based on its time-dependent activation at positive potentials, on its external DIDS, DPC, furosemide, $\mathrm{pH}$ and $\mathrm{Ca}^{2+}$ sensitivity (Uchida et al. 1993; Uchida et al. 1995; Waldegger and Jentsch 2000; Uchida and Sasaki 2005), and on the previously reported observation of both voltage-gated chloride channels from the kidney $(\mathrm{ClC}-\mathrm{K})$ transcripts and $\mathrm{ClC}-\mathrm{K}$ protein in IMCD 
(Uchida et al. 1993; Vandewalle et al. 1997; Waldegger et al. 2002) we inferred that this anion conductance could be mediated by $\mathrm{ClC}-\mathrm{K}$ channels.

\section{Materials and Methods}

\section{Cell culture}

Wistar rats (175-225 g) were grown and handled in accordance with the guidelines and principles of the Institutional Animal Care Committee of the National Autonomous University of Mexico. Primary cultures of rat IMCD cells were obtained using a modified hypotonic lysis method as described previously (Escobar et al. 2004). Cells were plated on glass cover slips contained in $35 \mathrm{~mm}$ Petri culture dishes, and cultured in Dulbecco's modified Eagle medium (DMEM, GIBCO) supplemented with 10\% fetal bovine serum (GIBCO), antibiotics and insulin, at $37^{\circ} \mathrm{C}$ with an air/5\% $\mathrm{CO}_{2}$ atmosphere. Cells were studied 6-11 days after plating. At this time, cells formed confluent cell monolayers exhibiting blister formation, an evidence of cell polarization and transepithelial transport. As described in Escobar et al. (2004), electrophysiological recordings were performed in cells exhibiting principal or IMCD cell morphology (as evidenced by positive $D$. biflorus lectin binding), the main cell population in our cultures.

\section{Whole-cell clamp recordings}

Membrane currents were studied with the perforatedpatch whole-cell clamp technique, as previously described (Escobar et al. 2004; Bolívar et al. 2008). Coverslips with a confluent-cell monolayer were placed in a superfusion chamber

In a first group of experiments, cells were maintained in a standard control bath solution containing (in $\mathrm{mM}$ ): $\mathrm{NaCl}$ 45.5, $\mathrm{KCl} 5, \mathrm{NaH}_{2} \mathrm{PO}_{4} 2.5, \mathrm{Na}_{2} \mathrm{HPO}_{4} 10$, calcium citrate 0.4 $\left(1.2 \mathrm{Ca}^{2+}\right), \mathrm{MgCl}_{2} 1$, glucose 10, alanine $1, \mathrm{NaHCO}_{3} 17.5$, $\mathrm{Na}$-HEPES 54, as well as amiloride $3 \times 10^{-7} \mathrm{M}$ and fenol red $16 \mathrm{mg} / \mathrm{l}$. After equilibration with a mixture of air/5\% $\mathrm{CO}_{2}\left(\mathrm{CO}_{2}\right.$ partial pressure $\left.\left(\mathrm{PCO}_{2}\right), 29.25 \mathrm{mmHg}\right), \mathrm{pH}$ was stabilized at 7.4. Other bath solutions used in this group of experiments were: 1) a "low $\mathrm{Cl}^{-} /$low $\mathrm{HCO}_{3}{ }^{-}$bath solution" containing $1 \mathrm{mM} \mathrm{NaCl}\left(8 \mathrm{mM} \mathrm{Cl}^{-}\right), 3 \mathrm{mM} \mathrm{NaHCO}$ and $113 \mathrm{mM} \mathrm{Na}$-HEPES ; 2) a "low $\mathrm{HCO}_{3}{ }^{-}$bath solution" containing $3 \mathrm{mM} \mathrm{NaHCO}_{3}$ and $68.5 \mathrm{mM} \mathrm{Na}$-HEPES $\left(\mathrm{PCO}_{2}\right.$ was lowered to $\sim 5 \mathrm{mmHg}$ to reach a $\mathrm{pH}$ of 7.4$) ; 3$ ) a "low $\mathrm{Cl}^{-}$bath solution" containing $1 \mathrm{mM} \mathrm{NaCl}\left(8 \mathrm{mM} \mathrm{Cl}^{-}\right)$and 98.5 mM Na-HEPES; 4) a "high $\mathrm{Cl}^{-}$bath solution" containing $95.5 \mathrm{mM} \mathrm{NaCl}\left(102.5 \mathrm{mM} \mathrm{Cl}^{-}\right)$and $4 \mathrm{mM} \mathrm{Na}$-HEPES; and 5) a "high $\mathrm{HCO}_{3}{ }^{-}$bath solution" containing 52.5
$\mathrm{mM} \mathrm{NaHC}_{3} \mathrm{O}$ and $19 \mathrm{mM} \mathrm{Na-HEPES} \mathrm{(the} \mathrm{solution} \mathrm{was}$ equilibrated with $15 \% \mathrm{CO}_{2}\left(\mathrm{PCO}_{2} 87.75 \mathrm{mmHg}\right)$ in order to obtain a $\mathrm{pH}$ of 7.4.

In a second group of experiments, cells were initially bathed in the high $\mathrm{Cl}^{-}$solution described above ("high $\mathrm{Cl}^{-}$control bath solution), and, thereafter, the $\mathrm{PCO}_{2}$ of this solution was modified to obtain either a solution with a $\mathrm{pH}$ of $7.1\left(\mathrm{PCO}_{2} 58.2 \mathrm{mmHg}\right)$ or a solution with a $\mathrm{pH}$ of 7.7 $\left(\mathrm{PCO}_{2} 14.7 \mathrm{mmHg}\right)$.

In a third group of experiments, phosphates in the high $\mathrm{Cl}^{-}$control bath solution were replaced by $\mathrm{Na}$-HEPES, and the calcium citrate concentration was modified to obtain either a solution containing $0.5 \mathrm{mM} \mathrm{Ca}^{2+}$ or a solution containing $2 \mathrm{mM} \mathrm{Ca}^{2+}$. Cells were initially studied in the $0.5 \mathrm{mM} \mathrm{Ca}^{2+}$ solution.

In a fourth group of experiments, cells were initially bathed in a "chloride control $\left(\mathrm{HCO}_{3}{ }^{-}\right.$free, non $\mathrm{CO}_{2}$ equilibrated) bath solution" containing $113 \mathrm{NaCl}\left(120 \mathrm{mM} \mathrm{Cl}^{-}\right)$, $5 \mathrm{Na}$-HEPES; thereafter, $112 \mathrm{mM} \mathrm{NaCl}$ in this solution was equimolary replaced by $\mathrm{NaBr}$ (bromide solution), $\mathrm{NaI}$ (iodide solution) or $\mathrm{NaNO}_{3}$ (nitrate solution).

Osmolarity of every solution was adjusted, with urea, to $300 \mathrm{mOsm} / \mathrm{l}$. All experiments were performed at room temperature $\left(20-25^{\circ} \mathrm{C}\right)$. Micropipettes (Kimax-51 glass; Kimble), were filled from the tip with a pipette solution composed of (in $\mathrm{mM}$ ): $\mathrm{KCl} 114, \mathrm{NaCl} 7.5, \mathrm{NaH}_{2} \mathrm{PO}_{4} 2.5$, $\mathrm{K}_{2} \mathrm{HPO}_{4} 10, \mathrm{CaCl}_{2} 1.54, \mathrm{MgCl}_{2} 1$, glucose 10 and EGTA 2.5; $\mathrm{pH}$ 7.4. Pipette filling was completed, from the back, with the same pipette solution containing, in addition, $200 \mu \mathrm{g} / \mathrm{ml}$ amphotericin B. Once filled, micropipettes had a resistance of 2-4 $\mathrm{M} \Omega$. Seals were obtained after pipettes had contacted the cell membrane and a gentle suction had been applied. Perforated-patch whole-cell clamp configuration was obtained 4-8 min after the membrane contact, as monitored when a voltage square pulse $(20 \mathrm{mV}, 5 \mathrm{~ms})$ evoked a capacitative current transient shorter than $3 \mathrm{~ms}$. Membrane potential was clamped at $-50 \mathrm{mV}$. The voltage-clamp protocols were generated and the membrane currents were acquired with the Axopatch-1D under the control of the pClamp software (v.6; Axon Inst.) running on a Pentium 1 PC (Gateway 2000) and using a Digidata $1200 \mathrm{~A} / \mathrm{D}$ converter (Axon Inst.). Membrane currents were low-pass filtered (at $5 \mathrm{kHz}$ ), digitized and stored on the hard disk of the computer for subsequent analysis. Analysis was performed using the Clampfit module of pClamp software, and curve fitting was performed using Sigmaplot (Jandel Scientific). As previously reported (Escobar et al. 2004; Bolívar et al. 1987), the time course of the capacitative current (evoked by a pulse from -50 to $-60 \mathrm{mV}$ ) exhibited monoexponential decay, evidencing the absence of electrical coupling between cells, an indispensable condition for achieving space clamp. A basic stimulation protocol was used in every cell: from a holding potential of $-50 \mathrm{mV}$, 
a series of $720 \mathrm{~ms}$ voltage steps between -160 and $80 \mathrm{mV}$ were applied in $20 \mathrm{mV}$ increments and with $8 \mathrm{~s}$ intervals between the steps. After each voltage step, membrane potential was fixed at $-150 \mathrm{mV}$ during $80 \mathrm{~ms}$, to record the tail currents. The voltage clamp protocols used to determine the slope conductance and the reversal potential, as well as those used to study the tail currents time-dependent kinetics will be described below.

\section{Current kinetics analysis}

Depolarization-activated, time-dependent current: it was obtained from currents recorded at membrane potentials between 20 and $80 \mathrm{mV}$, by subtracting instantaneous current (current values obtained within the first $0.4 \mathrm{~ms}$ of voltage pulses).

Instantaneous current: current recorded during the first $0.4 \mathrm{~ms}$ of voltage pulses is defined as instantaneous current. Instantaneous current corresponding to voltages steps from -120 to $-20 \mathrm{mV}$ was plotted against voltage and instantaneous linear slope conductance was calculated by linear regression. Instantaneous linear current at voltages from 0 to $80 \mathrm{mV}$ was calculated by extrapolation. Cells exhibiting inward rectification (Bolívar et al. 2008) were excluded. Outward rectifying instantaneous current was calculated by subtracting linear current from the current measured at the onset of the voltage pulses from 0 to $80 \mathrm{mV}$.

Time course of the depolarization-activated outward current: It was studied using instantaneous current-subtracted traces from cells having currents that reach an apparent plateau at the end of the $80 \mathrm{mV}$ pulses. The time course of current activation was fitted with a sum of two exponential functions

$$
I_{t}=A\left\{\left[1-e^{-\frac{t}{\tau_{f}}}\right]+\left[1-e^{-\frac{t}{\tau_{s}}}\right]\right\}
$$

where $I_{t}$ is the current measured at time $=t$, A is a constant related to the maximum value that can be reached by the depolarization-activated and time-dependent current, $\tau_{\mathrm{f}}$ and $\tau_{\mathrm{s}}$ are the time constants of activation, $\tau_{\mathrm{f}}$ being faster than $\tau_{\mathrm{s}}$. In some cells at the more depolarizing potentials, and in every cell at a membrane potential of $20 \mathrm{mV}$ the time-dependent kinetics was fitted with a single exponential function (Eq. 1 without the second exponential term).

Voltage-dependence of the depolarization-activated outward current activation: tail currents $(-150 \mathrm{mV})$ after each voltage step were linear current subtracted. The resultant tail currents $\left(\mathrm{i}_{\mathrm{V}}\right)$ corresponding to each voltage step $(\mathrm{V})$ were normalized as fractions of the tail current corresponding to the $80 \mathrm{mV}$ step $\left(\mathrm{i}_{80}\right)$. The normalized values were fitted with the following (Boltzmann type) equation

$$
\frac{i_{v}}{i_{80} c}=\frac{i_{v}}{i_{\max }}=\left\{1+e^{\frac{\left(V_{o}-V\right)}{k}}\right\}^{-1}
$$

where $\mathrm{c}$ is a correction factor to account for a non maximal activation of the outward current at $80 \mathrm{mV}, \mathrm{i}_{\max }$ is the estimated maximum value that can be reached by $i_{v}, V_{o}$ is the voltage of half maximal activation, and $k$ is a constant which gives the steepness of the voltage dependence.

Tail currents time-dependent kinetics: from a holding potential of $-50 \mathrm{mV}$, the current was activated with a prepulse to $80 \mathrm{mV}$ during $1.1 \mathrm{~s}$, and tail currents were evoked by a series of $880 \mathrm{~ms}$ voltage steps between -60 and $60 \mathrm{mV}$, applied in $20 \mathrm{mV}$ increments and at $16 \mathrm{~s}$ intervals. Tail currents, recorded between -60 and $-20 \mathrm{mV}$, were instantaneous currents subtracted and the time course of its deactivation was fitted with Eq. 1.

Voltage ramps, reversal potential and v-ramp response slope conductance: from a holding potential of $-50 \mathrm{mV}$, the current was activated with a prepulse to $80 \mathrm{mV}$ during $1.1 \mathrm{~s}$. Voltage was returned to $-60 \mathrm{mV}$ for $3 \mathrm{~ms}$ allowing occurrence of capacitative current, and then voltage was ramped to $60 \mathrm{mV}$ over either $30 \mathrm{~ms}$ or $7 \mathrm{~ms}$. Time-independent linear current, as measured from recordings obtained with a similar voltage protocol in which a prepulse to $-80 \mathrm{mV}$ was applied, was subtracted. The so determined current response to the voltage ramp (current $\mathrm{v}$-ramp response) was plotted against voltage; the reversal potential was measured at the point where the current value crossed the voltage axis, and the slope conductance was determined by linear regression at voltages between $\pm 20 \mathrm{mV}$ of the reversal potential. Three to six prepulse-ramp current responses per cell were recorded and, at least, 3 cells per experimental condition were studied.

\section{Statistical analysis}

All experimental results are expressed as means \pm S.E.M. Comparison among mean values was made by Student's $t$-test for paired data. Values of $p<0.05$ were considered significant.

\section{Results}

\section{Time-dependent outward rectifying current and instanta- neous linear current}

In our previous studies (Escobar et al. 2004; Bolívar et al. 2008), performed in $\mathrm{Cl}^{-}$and $\mathrm{HCO}_{3}{ }^{-}$free solutions, we described the main cationic currents exhibited by IMCD cells in primary culture. Now we employ $\mathrm{Cl}^{-}$and, usually, $\mathrm{HCO}_{3}{ }^{-}$containing solutions, to study the main anionic currents present in the membrane of these cells. 
A depolarization-activated, time-dependent outward current $\left(\mathrm{I}_{\text {ovt }}\right)$ was observed in about $50 \%$ of the studied cells (Figure 1A). It activates at a potential close to $20 \mathrm{mV}$, requires more than $720 \mathrm{~ms}$ to complete its activation at potentials between 20 and $80 \mathrm{mV}$, and appears to activate more quickly with larger depolarization (see below). Figure $1 \mathrm{~B}$ illustrates the currents observed in $\mathrm{I}_{\text {ovt }}$-expressing cells: an instantaneous current $\left(\mathrm{I}_{\text {ins }}\right)$ exhibiting linear and outward rectifying components and $\mathrm{I}_{\mathrm{ovt}}$, whose activation produces prominent tail currents at $-150 \mathrm{mV}$. $\mathrm{I}_{\text {ins }}$ has a time-dependent deactivation at potentials below $-60 \mathrm{mV}$ (Figure 1A, bottom 5 records). A current-voltage (I-V) relationship of the averaged maximal current amplitude of $35 \mathrm{I}_{\mathrm{ovt}}$-expressing cells (selected on the basis of its voltagedependent activation correction factor, $\mathrm{c}<1.3$; see Eq. 2 in Materials and Methods) is shown in Figure 1C (circles); note the presence of outward rectification and the zero current potential $\left(\mathrm{E}_{0 \text { cur }}\right)$ close to $0 \mathrm{mV}(1.1 \pm 0.5 \mathrm{mV})$ of the instantaneous linear current. The outward rectification is mainly due to $\mathrm{I}_{\mathrm{ovt}}(81.3 \pm 2.8 \%$ at $80 \mathrm{mV})$. In order to determine whether, in IMCD cells, $\mathrm{I}_{\text {ins }}$ was related to $\mathrm{I}_{\text {ovt }}$, we looked for a correlation between them. Figure 1D shows a plot of single cell $\mathrm{I}_{\text {ins }}$ linear slope conductance as a function of the corresponding $\mathrm{I}_{\text {ovt }}$ chord conductance (determined at $80 \mathrm{mV}$, assuming an $\mathrm{E}_{\mathrm{rev}}=10 \mathrm{mV}$, see below). This plot revealed a significant correlation between the two currents $(r=0.75$, slope $=0.69, p<0.0001, n=35)$. This correlation suggests that $\mathrm{I}_{\mathrm{ovt}}$ channels have a non voltage-dependent activity that contributes to the linear current. A non voltage-dependent activity of $\mathrm{I}_{\text {ovt }}$ channels is also suggested by the $\mathrm{I}_{\text {ins }}$ time-dependent deactivation at potentials below $-60 \mathrm{mV}$.

\section{Time-dependent kinetics and voltage dependence of $I_{o v t}$ activation}

The time dependence of $\mathrm{I}_{\text {ovt }}$ activation was studied in those cells that appears to reach an apparent plateau at the $80 \mathrm{mV}$ pulse end $(n=10)$. In most of these cells, the time course of current activation was well fitted by a sum of two exponential functions (Eq. 1 in Materials and Methods) as shown in Figure 2A. Figure 2B shows a plot of the mean value of $\tau_{\mathrm{f}}$ as a function of voltage. All the plotted values exhibit a significant difference between them, indicating that the
A

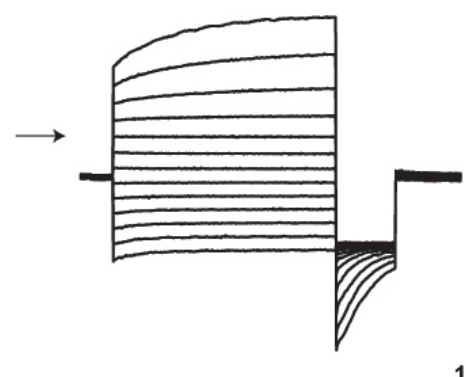

B

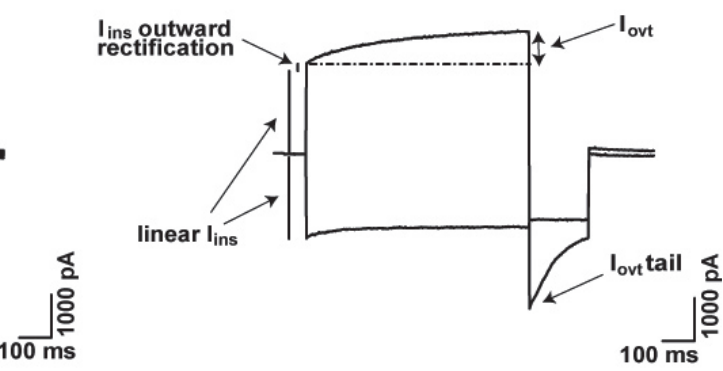

C

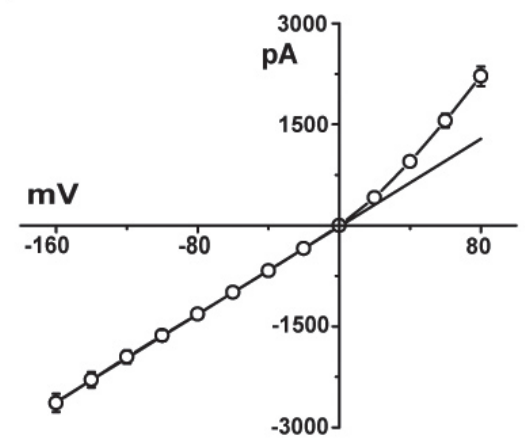

D

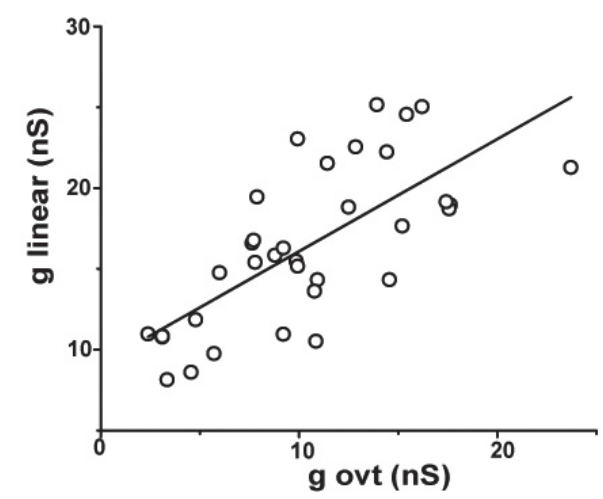

Figure 1. Depolarization-activated, time-dependent outward currents $\left(\mathrm{I}_{\text {ovt }}\right)$ in IMCD cells. A. Superimposed traces of current recorded from an $\mathrm{I}_{\mathrm{ovt}}$-expressing cell. Arrow indicates zero current level and outward currents are upward in this and all subsequent current traces. B. Two of the current traces shown in A (those evoked by the -160 and $60 \mathrm{mV}$ voltage steps) are separately shown to illustrate: the instantaneous $\left(\mathrm{I}_{\text {ins }}\right.$ ) linear current (its amplitude is represented by the vertical bars at left, above and below the base line); the $\mathrm{I}_{\text {ins }}$ outward rectification (its amplitude corresponds to the single vertical bar at left); the depolarization-activated, time-dependent outward current ( $\mathrm{I}_{\text {ovt }}$; trace above the dashed line, whose amplitude corresponds to the vertical two heads arrow at right); and the $\mathrm{I}_{\text {ovt }}$ tail current at $-150 \mathrm{mV}$. C. I-V relationship of the mean values $(n=35)$ of total maximal current (circles); the straight line is the linear fit of $\mathrm{I}_{\text {ins }}$ extrapolated to the more positive voltage values, to

show the outward rectification. When not shown, error bars are smaller than symbols. D. Single cell linear $\mathrm{I}_{\text {ins }}$ slope conductance ( $\mathrm{g}$ linear) is plotted as a function of the corresponding $\mathrm{I}_{\mathrm{ovt}}$ chord conductance ( $\mathrm{g}$ ovt) at $80 \mathrm{mV}$ (both conductances determined in the same group of 35 cells). The straight line shows the linear regression fit to the data. 
time dependence of $\mathrm{I}_{\mathrm{ovt}}$ activation is voltage-dependent. $\tau_{\mathrm{s}}$ shows a slight voltage dependence, from $315.1 \pm 56.1 \mathrm{~ms}$ at $80 \mathrm{mV}$ to $601.9 \pm 117.7 \mathrm{~ms}$ at $40 \mathrm{mV}(p<0.04 ; n=6$; not shown). The voltage dependence of $\mathrm{I}_{\text {ovt }}$ activation was well described by a Boltzmann type equation (Eq. 2 in Materials and Methods; Figure 2C). The mean values of the activation parameters were $\mathrm{V}_{\mathrm{o}}=32.03 \pm 1.29 \mathrm{mV}, k=22.60 \pm 0.68 \mathrm{mV}$, and $c=1.12 \pm 0.01(n=35)$, so that, in the selected cells, within $720 \mathrm{~ms}$ at $80 \mathrm{mV}$ the $\mathrm{I}_{\text {ovt }}$ voltage-dependent activation was about $83 \%$ of its full activation.

$I_{\text {ovt }} v$-ramp response and anionic nature of $I_{\text {ovt }}$

Since in our previous studies, performed in the absence of any permeating anion (Escobar et al. 2004; Bolívar et al. 2008), we have never observed the $I_{\text {ovt }}$ current, we assumed that this is an anionic current. To test this assumption, we analyzed, under various ionic conditions, the currents flowing during a $30 \mathrm{~ms}$ or a $7 \mathrm{~ms}$ voltage clamp ramps from -60 to $60 \mathrm{mV}$ (henceforth called $\mathrm{v}$-ramp response) applied $3 \mathrm{~ms}$ after a $1.1 \mathrm{~s}$ prepulse to either 80 or $-80 \mathrm{mV}$ in order to, respectively, activate or not $\mathrm{I}_{\text {ovt. }}$. The results of these procedures are shown in Figure 3A and B. Figure 3A shows the currents recorded during the prepulses and the ramps, and Figure $3 \mathrm{~B}$ shows the $\mathrm{v}$-ramp responses recorded when $\mathrm{I}_{\text {ovt }}$ was activated (trace $\mathrm{a}$ ) or not (trace $\mathrm{b}$ ); the subtraction $(\mathrm{a}-\mathrm{b})$ corresponds to the $\mathrm{I}_{\text {ovt }} \mathrm{V}$-ramp response (trace $\mathrm{c}$ ). To validate the use of these ramps in the study of $\mathrm{I}_{\text {ovt }}$ conductance properties, we analyzed $880 \mathrm{~ms}$ tail currents at membrane potentials between -60 and $-20 \mathrm{mV}$, recorded after a $1.1 \mathrm{~s}$ prepulse to $80 \mathrm{mV}$. Tail currents time-dependent deactivation was well fitted by a sum of two exponential functions (Eq. 1 in Materials and Methods) as shown in Figure 3C. Mean values of $\tau_{\mathrm{f}}$ were $174.6 \pm 25.0,225.7 \pm 35.5$ and $283.9 \pm 48.7 \mathrm{~ms}(n=20)$ at $-60,-40$ and $-20 \mathrm{mV}$, respectively. These values are much larger than the $30 \mathrm{~ms}$ duration of our longer voltage clamp ramp. The use of these voltage clamp ramps is also validated by the plot shown in Figure 3D. Single cell $\mathrm{I}_{\text {ovt }}$ slope conductance (as determined from $\mathrm{I}_{\text {ovt }} \mathrm{V}$-ramp response) is plotted as a function of the corresponding $\mathrm{I}_{\text {ovt }}$ cord conductance (determined at $80 \mathrm{mV}$ ); $\mathrm{v}$-ramps of $30 \mathrm{~ms}$ and $7 \mathrm{~ms}$ duration were used for this plot. The linear fit obtained $(r=0.93$, slope $=0.96, p<0.0001, n=107)$ corroborates the expected good correlation between both conductance. Hence, $30 \mathrm{~ms}$ or 7 $\mathrm{ms}$ voltage clamp ramps from -60 to $60 \mathrm{mV}$ are adequate to study the $\mathrm{I}_{\text {ovt }}$ conductance properties. Figure $3 \mathrm{E}$ shows the currents recorded, during the prepulses, in the same cell, at two ionic bath conditions: standard control solution (black traces) and a low $\mathrm{Cl}^{-} /$low $\mathrm{HCO}_{3}{ }^{-}$solution (gray traces). $\mathrm{I}_{\mathrm{ovt}}$, present in the first condition, was absent, and replaced by a slow deactivating current, in the latter condition. It also shows (dashed line trace) the outward current suppressed by this maneuver, to illustrate the current mediated by $\mathrm{I}_{\mathrm{ovt}}$ channels. Figure $3 \mathrm{~F}$ shows the $\mathrm{I}_{\text {ovt }} \mathrm{V}$-ramp responses corresponding to the experiment illustrated in E. Note that in the control condition, the $\mathrm{I}_{\text {ovt }} \mathrm{v}$-ramp response inverts at a potential close to $12 \mathrm{mV}(11.8 \pm 1.1 \mathrm{mV} ; n=9)$; and that in the low $\mathrm{Cl}^{-}$/low $\mathrm{HCO}_{3}{ }^{-}$condition, this response has a decreased slope conductance (it decreased from $9.02 \pm 0.12$ $\mathrm{nS}$ to $0.64 \pm 0.07 \mathrm{nS} ; p<0.0004, n=9$ ) and appears to invert

A

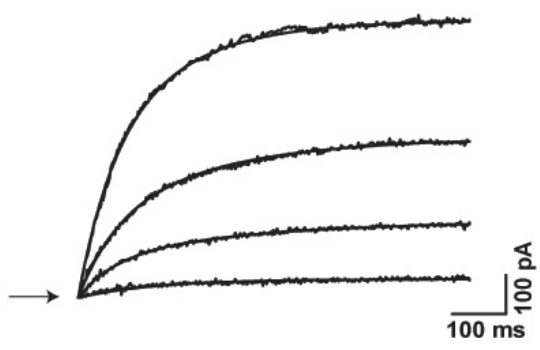

B

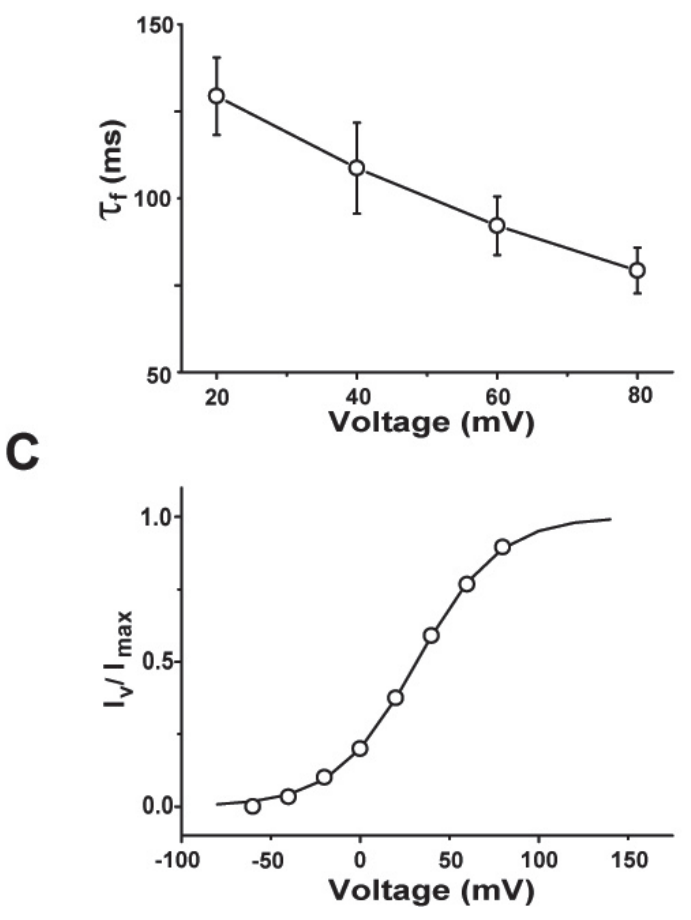

Figure 2. Kinetic characteristics of $\mathrm{I}_{\text {ovt }}$. A and B: time-dependent kinetics. A. Noisy traces are $\mathrm{I}_{\text {ins }}$ subtracted currents in response to voltage steps of (from bottom to top): 20, 40, 60 and $80 \mathrm{mV}$. The lines superimposed to the recordings are the best fits obtained with Eq. 1 . $\mathrm{I}_{\mathrm{ovt}}$ activation becomes faster as depolarizing voltage increases. B. Mean values of the fast activation time constant $\left(\tau_{\mathrm{f}}\right.$, $n=10$ ) plotted against the membrane potential, note their voltage dependence. C. Voltage-dependent activation. Mean value of the normalized tail currents at $-150 \mathrm{mV}\left(\mathrm{I}_{\mathrm{V}} / \mathrm{I}_{\max } ; n=35\right)$ plotted against membrane potential. The superimposed S-shaped curve corresponds to the best fit obtained with Eq. 2. 
close to $60 \mathrm{mV}$. However, this apparent reversal potential should be taken with caution due to the deactivation of the time-dependent outward current observed during the $80 \mathrm{mV}$ prepulse. Results shown in Figures $3 \mathrm{E}$ and $3 \mathrm{~F}$ indicate that $\mathrm{I}_{\text {ovt }}$ is an anionic current.

\section{Effect of anionic current blockers on $I_{\text {ovt }}$}

Anionic currents may be blocked by external 4,4'-diisothiocyanatostilbene-2,2'-disulfonic acid (DIDS), diphenylaminecarboxylate (DPC) and furosemide (Evans et al. 1986; Schultz et al. 1999; Jentsch et al. 2002; Qu et al. 2003; Uchida and Sasaki 2005), therefore we performed experiments to investigate if $\mathrm{I}_{\text {ovt }}$ is a DIDS- , DPC- and furosemide-sensitive current. Figure $4 \mathrm{~A}$ shows the currents recorded, during the prepulses, when the cell was bathed in the standard control solution (black traces), and when this solution contained $1 \mathrm{mM}$ DIDS (gray traces). In the presence of DIDS $\mathrm{I}_{\text {ovt }}$ amplitude was inhibited by $59.8 \pm$ $7.2 \%(n=12, p<0.0001)$, and $\mathrm{I}_{\text {ins }}$ was inhibited by $48.5 \pm$ $3.3 \%(n=12, p<0.0001)$; dashed line trace shows the current suppressed by DIDS. Figure $4 \mathrm{~B}$ shows the $\mathrm{I}_{\text {ovt }} \mathrm{V}$-ramp
A

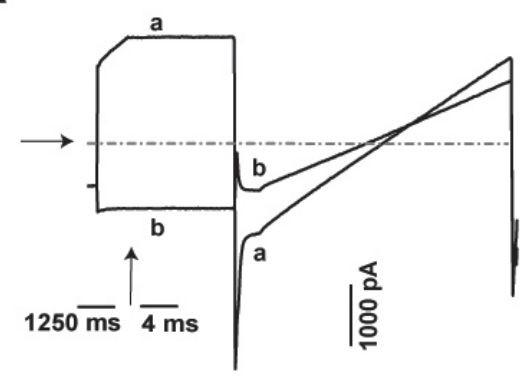

C

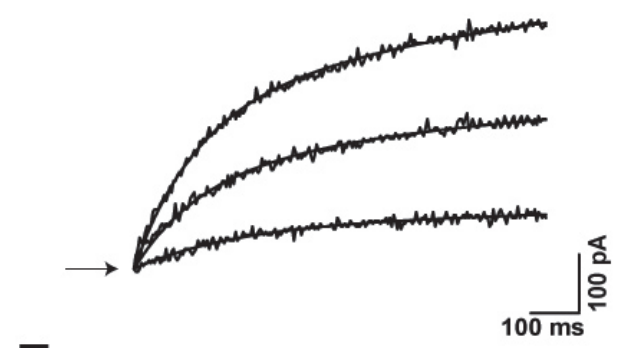

$\mathbf{E}$

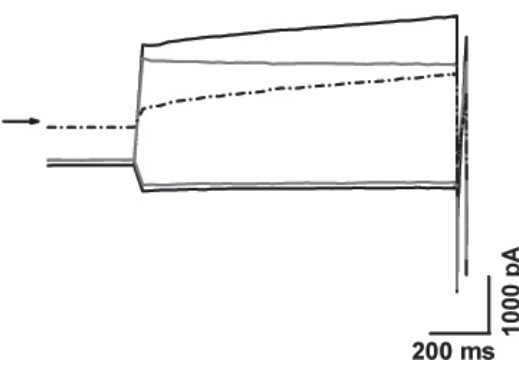

B

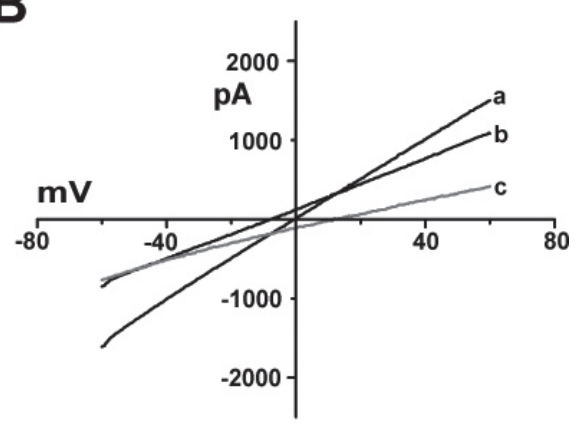

D

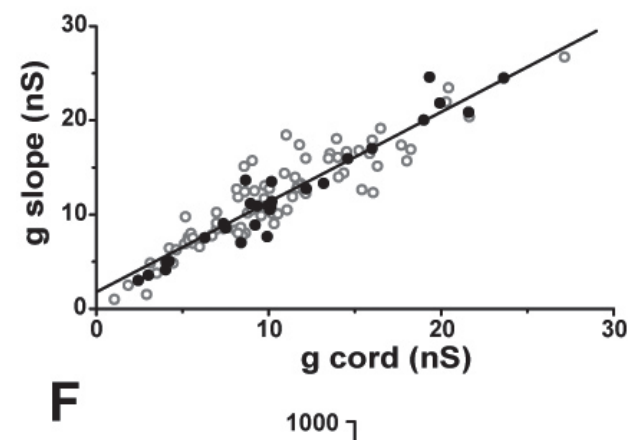

F pA

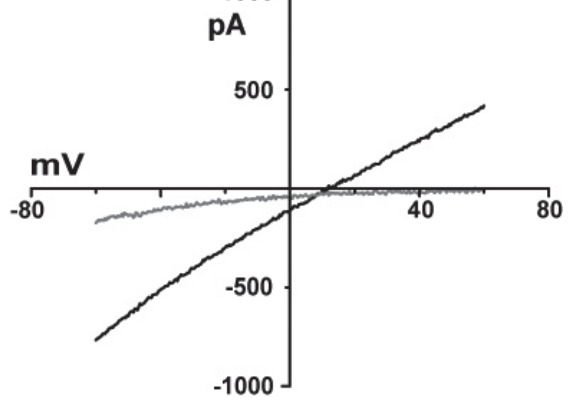

Figure 3. Prepulse $\mathrm{I}_{\text {ovt }}$ current recordings and $\mathrm{I}_{\text {ovt }}$ voltage-ramp current responses. A. Voltageramp (v-ramp; from -60 to $60 \mathrm{mV}$ ) current responses obtained when $\mathrm{I}_{\mathrm{ovt}}$ was activated with a prepulse to $80 \mathrm{mV}$ during $1.1 \mathrm{~s}$ (trace a; vertical arrow indicates time scale change) and when it was not activated (prepulse to $-80 \mathrm{mV}$; trace b). Dash and dot line indicates the zero current level. B. v-ramp current traces shown in $\mathrm{A}$, are here separately shown to illustrate the subtraction $(a-b)$, here defined as the $\mathrm{I}_{\text {ovt }} \mathrm{v}$-ramp response (trace c). C. Noisy traces are $\mathrm{I}_{\text {ins }}$ subtracted $\mathrm{I}_{\text {ovt }}$ tail currents at voltages of (from bottom to top): $-20,-40$ and $-60 \mathrm{mV}$. The lines superimposed to the recordings are the best fits obtained with Eq. 1. D. Single cell $\mathrm{I}_{\text {ovt }} \mathrm{V}$-ramp response slope conductance (g slope), as measured with the voltage-ramp protocols of $7 \mathrm{~ms}$ (open circles) and $30 \mathrm{~ms}$ (closed circles), is plotted as a function of its corresponding $\mathrm{I}_{\text {ovt }}$ cord conductance ( $\mathrm{g}$ cord). The straight line shows the linear regression fit to data. E. Current recordings obtained during the prepulses (to 80 and $-80 \mathrm{mV}$ ) in the same cell when bathed in the standard control solution (traces

in black) and after this solution were replaced by a low $\mathrm{Cl}^{-} /$low $\mathrm{HCO}_{3}{ }^{-}$solution (traces in gray); note the decrease in outward current amplitude induced by this replacement. The difference between the currents during the prepulse to $80 \mathrm{mV}$ is shown by the dashed line trace to illustrate, in this and subsequent similar figures, the outward current change induced by the experimental maneuver. $\mathrm{F}$. $\mathrm{I}_{\text {ovt }}$ v-ramp responses corresponding to the experiment described in E. Note that, when compared with its control (trace in black), the v-ramp response recorded in the low $\mathrm{Cl}^{-} /$low $\mathrm{HCO}_{3}{ }^{-}$condition (trace in gray) exhibits a decreased slope conductance and a shift in its (extrapolated) reversal potential to a value more positive than $60 \mathrm{mV}$. 
responses corresponding to the experiment illustrated in A. Note that, in the DIDS condition, this response exhibited a decreased slope conductance. $\mathrm{I}_{\text {ovt }} \mathrm{V}$-ramp response slope conductance decreased from $16.8 \pm 1.4 \mathrm{nS}$, in the control condition, to $4.6 \pm 0.6 \mathrm{nS}$, in the DIDS condition $(n=12$, $p<0.0001$ ), without a change in its reversal potential. On the other hand, Figure $4 \mathrm{C}$ shows the currents recorded, during the prepulses, when the cell was bathed in the standard control solution (black traces), and when this solution contained $1 \mathrm{mM}$ DPC (gray traces). In the presence of DPC $\mathrm{I}_{\text {ovt }}$ amplitude was inhibited by $67.3 \pm 5.3 \%$ $(n=12, p<0.0001)$, and $\mathrm{I}_{\mathrm{ins}}$ was inhibited by $45.9 \pm 7.9 \%$ $(n=12, p<0.0002)$; dashed line trace shows the current suppressed by DPC. Figure $4 \mathrm{D}$ shows the $\mathrm{I}_{\text {ovt }} \mathrm{v}$-ramp re- sponses corresponding to the experiment illustrated in C. $\mathrm{I}_{\text {ovt }} \mathrm{V}$-ramp response slope conductance decreased from $5.2 \pm 0.3 \mathrm{nS}$, in the control condition, to $2.0 \pm 0.3 \mathrm{nS}$, in the DPC condition $(n=12, p<0.0001)$, without a change in its reversal potential. Figure $4 \mathrm{E}$ shows the currents recorded, during the prepulses, when the cell was bathed in the standard control solution (black traces), and when this solution contained $1 \mathrm{mM}$ furosemide (gray traces). In the presence of furosemide $\mathrm{I}_{\text {ovt }}$ amplitude was inhibited by $37.3 \pm 1.6 \%(n=12, p<0.0001)$, and $\mathrm{I}_{\text {ins }}$ was inhibited by $4.6 \pm 0.5 \%(p<0.001)$. Figure $4 \mathrm{~F}$ shows the $\mathrm{I}_{\text {ovt }} \mathrm{V}$-ramp responses corresponding to the experiment illustrated in $\mathrm{E}$. The addition of furosemide induced a decrease in $\mathrm{I}_{\mathrm{ovt}}$ $\mathrm{v}$-ramp response slope conductance from $12.6 \pm 0.7 \mathrm{nS}$ to
A

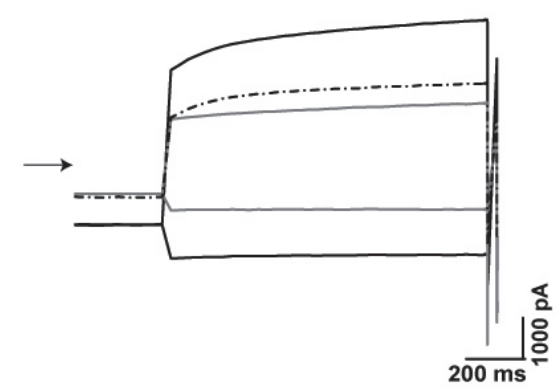

C

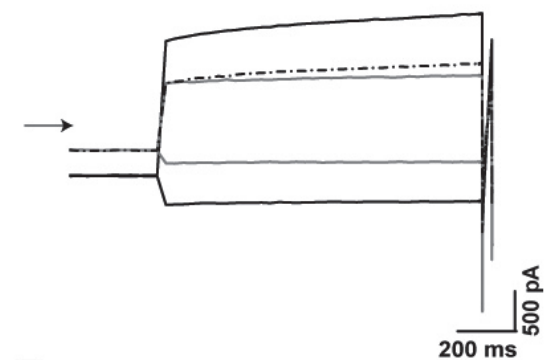

E

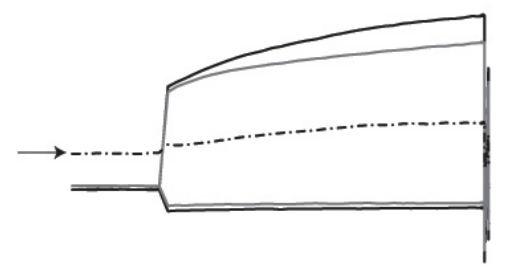

造

$200 \mathrm{~ms}$
B

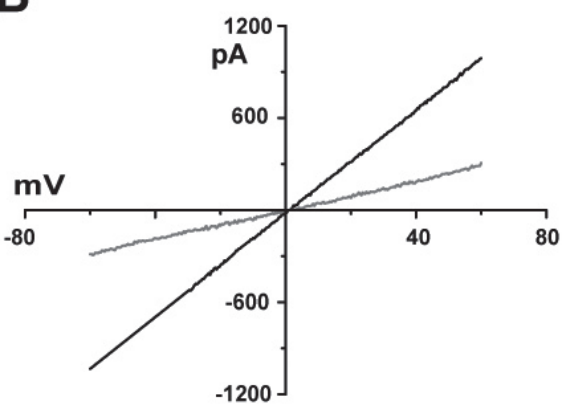

D

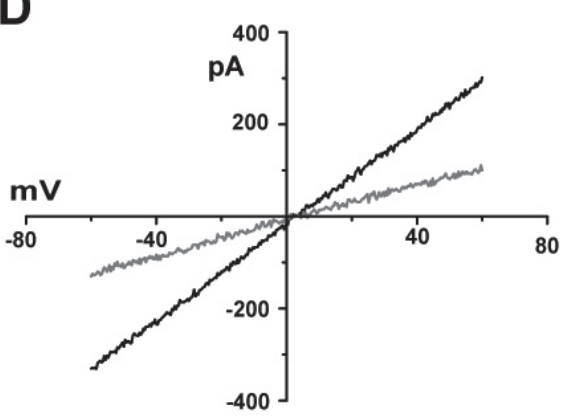

$\mathbf{F}$

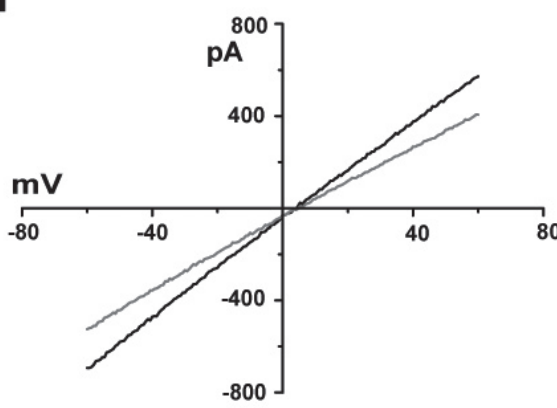

Figure 4. Effect of blocking agents on $\mathrm{I}_{\text {ovt }}$. A. Prepulse current recordings obtained in the same cell in the standard control condition (traces in black), and after its exposure to $1 \mathrm{mM}$ DIDS (traces in gray). In the presence of DIDS, $\mathrm{I}_{\text {ovt }}$ and $\mathrm{I}_{\text {ins }}$ were partially inhibited, as illustrated by the dashed line trace. $\mathrm{B}$. $\mathrm{I}_{\text {ovt }} \mathrm{v}$-ramp responses corresponding to the experiment described in A. Note that, when compared with its control (trace in black), the $\mathrm{v}$-ramp response recorded in the DIDS condition (trace in gray) exhibits a decreased slope conductance. C. Prepulse current recordings obtained in the same cell in the control condition (traces in black), and after its exposure to $1 \mathrm{mM}$ DPC (traces in gray). DPC partially inhibited $\mathrm{I}_{\mathrm{ovt}}$ and $\mathrm{I}_{\text {ins }}$, as illustrated by the dashed line trace. $\mathrm{D}$. $\mathrm{I}_{\text {ovt }} \mathrm{V}$-ramp responses corresponding to the experiment described in C. When compared with its control (trace in black), the $\mathrm{v}$-ramp response recorded in the DPC condition (trace in gray) exhibits a decreased slope conductance. E. Prepulse current recordings obtained in the same cell in the control condition (traces in black), and after its exposure to $1 \mathrm{mM}$ furosemide (traces in gray). $\mathrm{I}_{\mathrm{ovt}}$ amplitude decreases in the presence of furosemide. F. $\mathrm{I}_{\mathrm{ovt}} \mathrm{V}$-ramp responses corresponding to the experiment described in E. When compared with its control (trace in black), the v-ramp response recorded in the furosemide condition (trace in gray) exhibits a decreased slope conductance. 
$8.7 \pm 0.4 \mathrm{nS}(n=12, p<0.0001)$, without a change in its reversal potential.

\section{$\mathrm{Cl}^{-}$and $\mathrm{HCO}_{3}{ }^{-}$conductivity of $\mathrm{I}_{\text {ovt }}$}

In order to study the relative permeability of $\mathrm{I}_{\mathrm{ovt}}$ conductance to $\mathrm{Cl}^{-}$and $\mathrm{HCO}_{3}{ }^{-}$, we changed the concentration of these anions, one at a time. For these experiments we used $30 \mathrm{~ms}$ v-ramps. When the bath solution $\mathrm{Cl}^{-}$concentration was reduced from $52.5 \mathrm{mM}$ to $8 \mathrm{mM}$, the amplitude of $\mathrm{I}_{\mathrm{ovt}}$ during the prepulse to $80 \mathrm{mV}$ decreased (Figure 5A) from $833.8 \pm 63.0 \mathrm{pA}$ in the control condition to $544.8 \pm 36.0 \mathrm{pA}$ in the low $\mathrm{Cl}^{-}$condition $(p<0.0001 ; n=23)$. Reduction in bath $\mathrm{Cl}^{-}$concentration induces a decrease in $\mathrm{I}_{\text {ovt }} \mathrm{V}$-ramp response slope conductance (Figure 5B) from 12.19 $\pm 0.94 \mathrm{nS}$ to $8.31 \pm$ $0.51 \mathrm{nS}(p<0.0001 ; n=23)$; and a shift in its reversal potential to a slightly more depolarized value, from $8.13 \pm 0.65 \mathrm{mV}$ to $10.22 \pm 1.06 \mathrm{mV}(p<0.001)$. Then, $\mathrm{I}_{\mathrm{ovt}}$ is a $\mathrm{Cl}^{-}$carrying current. A decrease in $\mathrm{I}_{\text {ovt }}$ amplitude at $80 \mathrm{mV}$, from $862.3 \pm$ $52.7 \mathrm{pA}$ to $681.5 \pm 48.7 \mathrm{pA}(p<0.0001 ; n=24)$, was similarly observed when the bath solution $\mathrm{HCO}_{3}{ }^{-}$concentration was reduced from $17.5 \mathrm{mM}$ to $3.0 \mathrm{mM}$ (Figure $5 \mathrm{C}$ ). Bicarbonate reduction also induces a decrease in $\mathrm{I}_{\mathrm{ovt}} \mathrm{V}$-ramp response slope conductance (Figure 5D) from $13.09 \pm 0.88 \mathrm{nS}$ to $10.64 \pm 0.67 \mathrm{nS}(p<0.0001 ; n=24)$, and a shift in its reversal potential to a slightly more depolarized value, from $7.37 \pm$ $0.51 \mathrm{mV}$ to $8.78 \pm 0.64 \mathrm{mV}(p<0.0001)$. Then, $\mathrm{I}_{\text {ovt }}$ is also a $\mathrm{HCO}_{3}{ }^{-}$carrying current. We also explored the expected changes in $\mathrm{I}_{\text {ovt }}$ amplitude and $\mathrm{I}_{\text {ovt }} \mathrm{v}$-ramp response when the bath solution permeating anions concentration was increased. A rise in the $\mathrm{Cl}^{-}$concentration from $52.5 \mathrm{mM}$ to $102.5 \mathrm{mM}$ provokes an increase in the $\mathrm{I}_{\text {ovt }}$ amplitude (Figure 6A) from $300.8 \pm 32.9$ pA to $719.2 \pm 104.2 \mathrm{pA}(p<0.0002 ; n=12)$; and, as expected, it also evokes an increase in $\mathrm{I}_{\text {ovt }} \mathrm{V}$-ramp response slope conductance (Figure 6B), from $6.51 \pm 0.73 \mathrm{nS}$ to $13.18 \pm$ $1.78 \mathrm{nS}(p<0.0001 ; n=12)$; and a shift in its reversal potential to a less depolarized value, from $8.68 \pm 0.92 \mathrm{mV}$ to $6.87 \pm$ $0.74 \mathrm{mV}(p<0.002)$. When the $\mathrm{HCO}_{3}{ }^{-}$concentration was augmented from $17.5 \mathrm{mM}$ to $52.5 \mathrm{mM}$, the $\mathrm{I}_{\text {ovt }}$ amplitude increased (Figure 6C) from $447.8 \pm 80.4 \mathrm{pA}$ to $811.4 \pm 123.1$ $\mathrm{pA}(p<0.0001 ; n=16)$. $\mathrm{I}_{\text {ovt }} \mathrm{V}$-ramp response slope conductance also increased (Figure 6D) from $8.61 \pm 1.48 \mathrm{nS}$ to 13.68 $\pm 2.46 \mathrm{nS}(p<0.001 ; n=16)$, and its reversal potential shifted to a less positive value from $8.91 \pm 1.48 \mathrm{mV}$ to $5.57 \pm 1.30$ $(p<0.0001)$. When we express the observed changes in $\mathrm{I}_{\mathrm{ovt}}$ $\mathrm{v}$-ramp response slope conductance as slope conductance
A

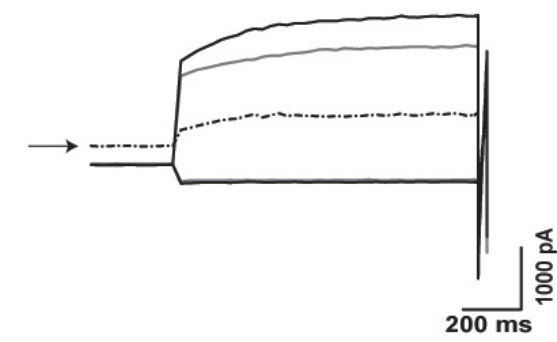

C

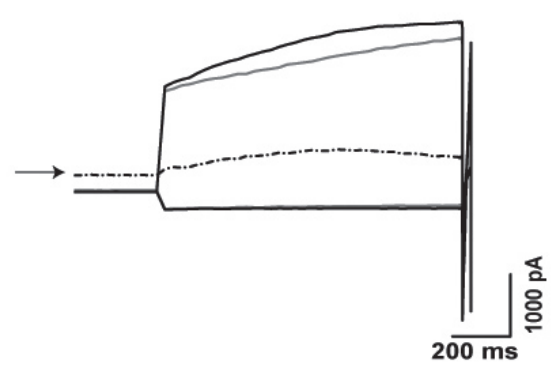

B

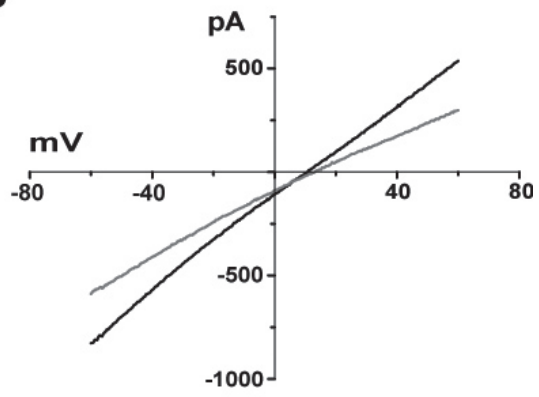

D

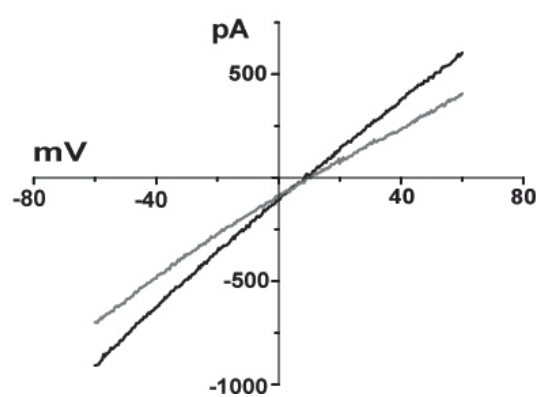

Figure 5. Effect of a decrease in bath solution $\mathrm{Cl}^{-}$or $\mathrm{HCO}_{3}{ }^{-}$concentration on $\mathrm{I}_{\text {ovt }}$. A. Prepulse current recordings obtained in the same cell in the standard control condition (traces in black), and after this solution was replaced by a low $\mathrm{Cl}^{-}$concentration solution (traces in gray). Note the decrease in outward $\mathrm{I}_{\text {ins }}$ and $\mathrm{I}_{\text {ovt }}$ amplitudes induced by this reduction in bath $\mathrm{Cl}^{-}$concentration. Dashed line trace illustrates the $\mathrm{Cl}^{-}$carried outward current suppressed by this maneuver. B. $\mathrm{I}_{\mathrm{ovt}}$ $\mathrm{v}$-ramp responses corresponding to the experiment described in A. Note that, when compared with its control (trace in black), the v-ramp response recorded in the low $\mathrm{Cl}^{-}$condition (trace in gray) exhibits a decreased slope conductance and a shift in its reversal potential to a slightly more positive value. C. Currents recorded during the prepulses in the same cell when bathed in the standard control

solution (traces in black) and after this solution was replaced by a low $\mathrm{HCO}_{3}{ }^{-}$concentration solution (traces in gray). Reduction in bath $\mathrm{HCO}_{3}{ }^{-}$concentration induces a decrease in $\mathrm{I}_{\text {ovt }}$ amplitude. Dashed line trace illustrates the $\mathrm{HCO}_{3}{ }^{-}$carried outward current suppressed by this maneuver. D. $\mathrm{I}_{\mathrm{ovt}} \mathrm{V}$-ramp responses corresponding to the experiment described in C. Note that, when compared with its control (trace in black), the v-ramp response recorded in the low $\mathrm{HCO}_{3}{ }^{-}$condition (trace in gray) exhibits a decreased slope conductance. 
change per $\mathrm{mM}$ of permeating anion concentration change, we obtain the following values for $\mathrm{Cl}^{-}$and $\mathrm{HCO}_{3}{ }^{-}$concentration reduction, respectively: $0.09 \pm 0.01 \mathrm{nS} / \mathrm{mM}(n=23)$ and $0.17 \pm 0.02 \mathrm{nS} / \mathrm{mM}(n=24)$. On the other hand, for $\mathrm{Cl}^{-}$and $\mathrm{HCO}_{3}{ }^{-}$concentration increments the following values are obtained: $0.13 \pm 0.02 \mathrm{nS} / \mathrm{mM}(n=12)$ and $0.14 \pm 0.03 \mathrm{nS} / \mathrm{mM}$ $(n=16)$. All together, these results indicate that $\mathrm{I}_{\text {ovt }}$ channels exhibit a similar conductivity to $\mathrm{HCO}_{3}{ }^{-}$and $\mathrm{Cl}^{-}$. However, when bath solution anion concentration was modified, the observed changes in $\mathrm{I}_{\text {ovt }} \mathrm{V}$-ramp response reversal potential were smaller than that expected for an anion selective conductance. When bath solution anion concentration is modified, if $\mathrm{I}_{\text {ovt }}$ channels localize at the basolateral membrane equivalent of the cultured cells, tight junctions between cells may hinder and delay the expected intercellular anions concentration changes (Cereijido et al. 1981; Contreras et al. 1989; Gonzalez-Mariscal et al. 1990). This could, at least in part, explain the smaller than expected changes in reversal potential. But, in that case, the tight junction diffusion barrier should attenuate the $\mathrm{I}_{\mathrm{ovt}} \mathrm{V}$-ramp response slope conductance changes, and this was not the case; furthermore, this diffusion barrier should also restrict the blocking agents access to
A
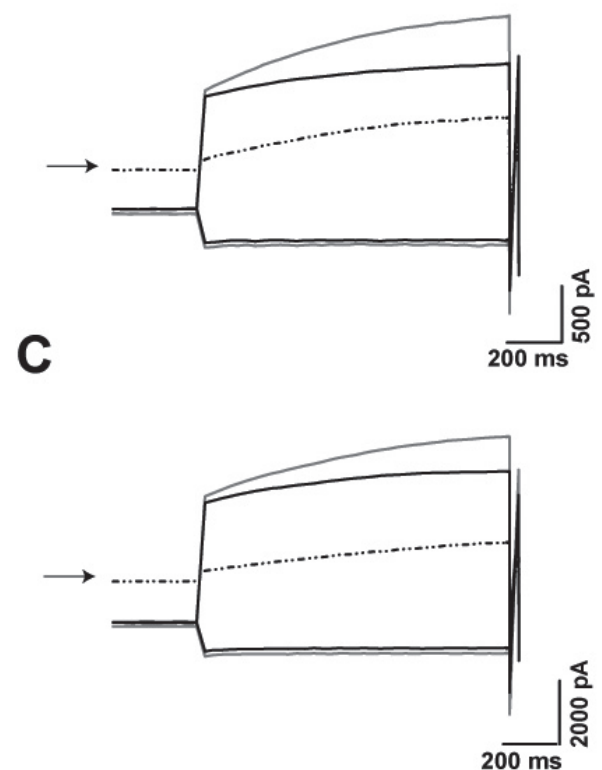

E

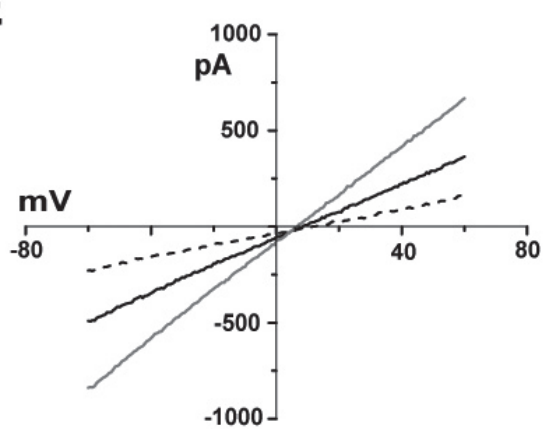

B
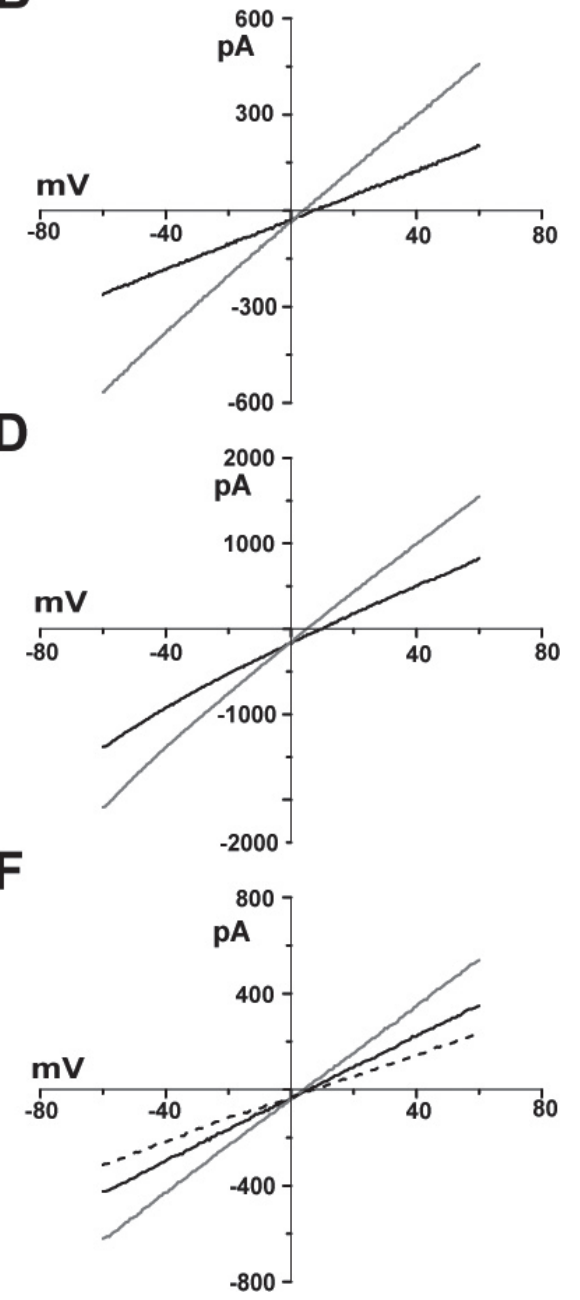

Figure 6. Effect of a change in bath solution $\mathrm{Cl}^{-}$or $\mathrm{HCO}_{3}{ }^{-}$concentration on $\mathrm{I}_{\text {ovt }}$. A. Prepulse current recordings obtained in the same cell in the standard control condition (traces in black), and after this solution was replaced by a high $\mathrm{Cl}^{-}$concentration solution (traces in gray). Note the increase in $\mathrm{I}_{\text {ovt }}$ amplitude induced by this increment in bath $\mathrm{Cl}^{-}$concentration. Dashed line trace illustrates the $\mathrm{Cl}^{-}$carried outward current promoted by this maneuver. B. $\mathrm{I}_{\text {ovt }} \mathrm{V}$-ramp responses corresponding to the experiment described in A. Note that, when compared with its control (trace in black), the v-ramp response recorded in the high $\mathrm{Cl}^{-}$condition (trace in gray) exhibits an increased slope conductance and a shift in its reversal potential to a less positive value. C. Currents recorded during the prepulses in the same cell when bathed in the standard control solution (traces in black) and after this solution was replaced by a high $\mathrm{HCO}_{3}{ }^{-}$concentration solution (traces in gray). Increment in bath $\mathrm{HCO}_{3}{ }^{-}$concentration induces an increase in $\mathrm{I}_{\text {ovt }}$ amplitude. Dashed line trace illustrates the $\mathrm{HCO}_{3}{ }^{-}$carried outward current added by this maneuver. D. $\mathrm{I}_{\text {ovt }} \mathrm{V}$-ramp responses corresponding to the experiment described in C. Note that, when compared with its control (trace in

black), the v-ramp response recorded in the high $\mathrm{HCO}_{3}{ }^{-}$condition (trace in gray) exhibits an increased slope conductance and a shift in its reversal potential to a less positive value. E. $\mathrm{I}_{\mathrm{ovt}} \mathrm{v}$-ramp responses recorded at three different bath solution $\mathrm{Cl}^{-}$concentrations: control concentration $\left(52.5 \mathrm{~m} \mathrm{M} \mathrm{Cl}^{-}\right.$, solid black trace), high concentration (102.5 $\mathrm{m} \mathrm{M} \mathrm{Cl}^{-}$, gray trace) and low concentration $\left(8 \mathrm{mM} \mathrm{Cl}^{-}\right.$, dashed trace). $\mathrm{F}$. $\mathrm{I}_{\mathrm{ovt}} \mathrm{V}$-ramp responses recorded at three different bath solution $\mathrm{HCO}_{3}{ }^{-}$concentrations: control concentration (17.5 $\mathrm{mM} \mathrm{HCO}_{3}{ }^{-}$, solid black trace), high concentration (52.5 $\mathrm{mM} \mathrm{HCO}_{3}{ }^{-}$, gray trace) and low concentration (3 $\mathrm{mM} \mathrm{HCO}_{3}{ }^{-}$, dashed trace). (E and $\mathrm{F}: \mathrm{I}_{\mathrm{ovt}} \mathrm{v}$-ramp responses studied in the tight junction open condition). 
the channels, however, only a several (4-8) minutes delay in blocking agents to attain their maximal inhibitory effect was observed (not shown). Having in mind that, in epithelial cells cultured on impermeable supports, basolateral membrane transport proteins localize mainly at the lateral membrane domain (Moreno et al. 2002; Padilla-Benavidez et al. 2010), we used a condition that favors the opening of tight junctions (Martínez-Palomo et al. 1980), in order to eliminate the possibility that a tight junction diffusion barrier affects our results. Cells were preincubated during $5 \mathrm{~min}$ in a $\mathrm{Ca}^{2+}$-free control bath solution plus $2 \mathrm{mM}$ EGTA, and maintained, thereafter, in the no- $\mathrm{Ca}^{2+}$ control bath (without EGTA), until currents from a cell exhibiting $\mathrm{I}_{\text {ovt }}$ were recorded. Bath was then changed to the standard control bath solution and experiments performed as before, but with the difference that 7 ms v-ramps were employed. Figure 6 (E and F) illustrates the results obtained in this "tight junctions open condition". When bath solution $\mathrm{Cl}^{-}$concentration was reduced from $55.5 \mathrm{mM}$ to $8 \mathrm{mM}, \mathrm{I}_{\text {ovt }} \mathrm{V}$-ramp response slope conductance decreased from $7.52 \pm 0.50 \mathrm{nS}$ to $3.57 \pm 0.32 \mathrm{nS}(n=18$, $p<0.0001$ ) and its reversal potential shifted to a slightly more depolarized value, from $8.44 \pm 0.61 \mathrm{mV}$ to $11.50 \pm 1.07 \mathrm{mV}$ $(p<0.0001)$; when the $\mathrm{Cl}^{-}$concentration was increased from $52.5 \mathrm{mM}$ to $102.5 \mathrm{mM}$ the slope conductance increased from
A

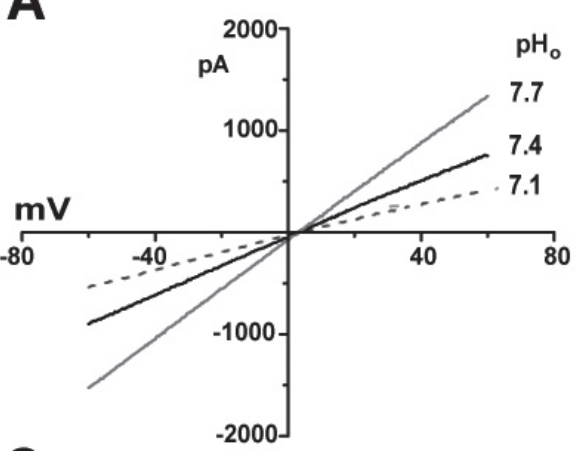

C

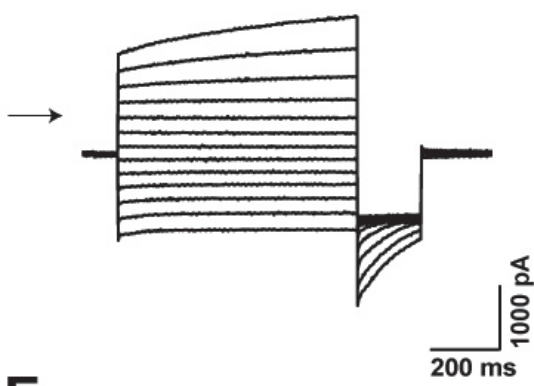

E

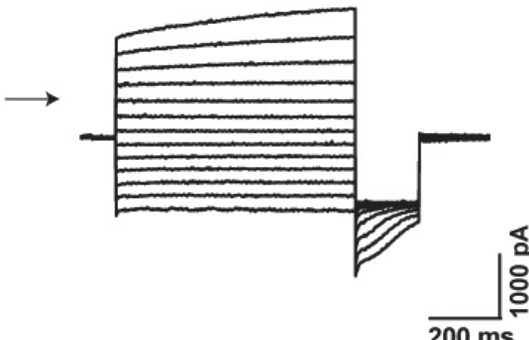

B

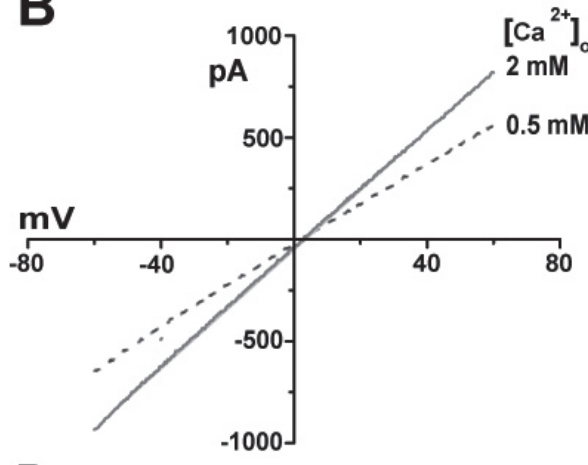

D

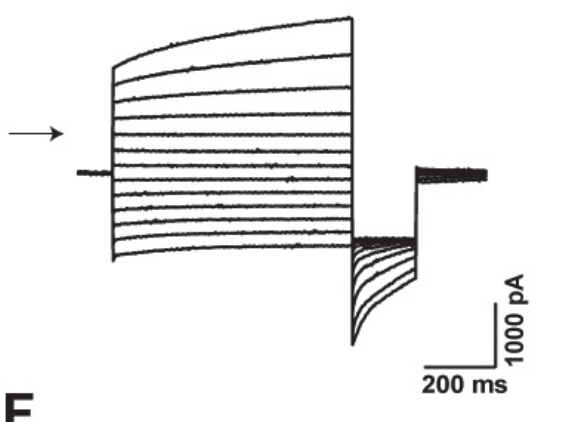

$\mathbf{F}$

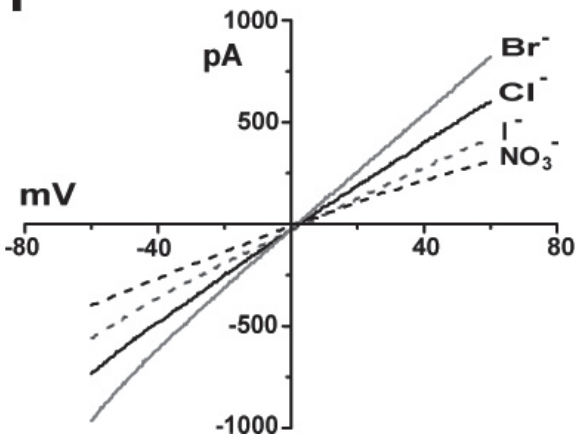

Figure 7. Effects of bath solution $\mathrm{pH}$ changes, bath solution $\mathrm{Ca}^{2+}$ concentration increase, and bath solution $\mathrm{Cl}^{-}$partial replacement by $\mathrm{Br}^{-}, \mathrm{I}^{-}$and $\mathrm{NO}_{3}{ }^{-}$on $\mathrm{I}_{\text {ovt }}$. A. $\mathrm{I}_{\text {ovt }}$ $\mathrm{v}$-ramp responses recorded in the same cell at three bath solution pH: 7.1 (dashed gray trace), 7.4 (black trace), and 7.7 (gray trace). Note that $\mathrm{I}_{\text {ovt }} \mathrm{v}$-ramp response slope conductance increased when $\mathrm{pH}$ was increased. B. $\mathrm{I}_{\mathrm{ovt}}$ $\mathrm{v}$-ramp responses recorded in the same cell at two bath solution $\mathrm{Ca}^{2+}$ concentrations: $0.5 \mathrm{mM}$ (dashed gray trace) and $2 \mathrm{mM}$ (gray trace). $\mathrm{I}_{\text {ovt }} \mathrm{V}$-ramp response slope conductance increased when $\mathrm{Ca}^{2+}$ concentration was increased. C. Chloride control solution $\left(120 \mathrm{mM} \mathrm{Cl}^{-}\right)$. D. Bromide solution $\left(8 \mathrm{mM} \mathrm{Cl}^{-}\right.$and $\left.112 \mathrm{mM} \mathrm{Br}^{-}\right)$. E. Iodide solution $\left(8 \mathrm{mM} \mathrm{Cl}^{-}\right.$and $\left.112 \mathrm{mM} \mathrm{I}^{-}\right)$. Note that, when compared with the control chloride condition, $\mathrm{I}_{\mathrm{ovt}}$ amplitudes and $\mathrm{I}_{\mathrm{ovt}}$ tail currents amplitudes were larger in the bromide condition and smaller in the iodide condition. ( $\mathrm{C}$ to $\mathrm{E}$ : superimposed traces of currents recorded (using our basic stimulation protocol; see Figure 1A and Materials and Methods) in the same cell at three different bath solution ionic conditions). F. $\mathrm{I}_{\mathrm{ovt}}$ $\mathrm{v}$-ramp responses recorded in the same single cell at the same three conditions as in $\mathrm{C}$ to $\mathrm{E}$, and at a nitrate condition $\left(8 \mathrm{mM} \mathrm{Cl}^{-}\right.$and $\left.112 \mathrm{mM} \mathrm{NO}_{3}{ }^{-}\right)$. When compared with its value in the chloride condition (black trace) the $\mathrm{v}$-ramp response recorded in the bromide condition (solid gray trace) exhibits an increased slope conductance; the v-ramp response recorded in the iodide condition (dashed gray trace) exhibits a decreased slope conductance; and that recorded in the nitrate condition (dashed black trace) exhibits an even smaller slope conductance. 
$6.75 \pm 0.47 \mathrm{nS}$ to $12.15 \pm 0.40 \mathrm{nS}(n=24, p<0.0001)$ and the reversal potential shifted from $8.80 \pm 0.47 \mathrm{mV}$ to 6.83 $\pm 0.31 \mathrm{mV}(p<0.001$; Figure $6 \mathrm{E})$. In the same way, when bath solution $\mathrm{HCO}_{3}{ }^{-}$concentration was reduced from 17.5 to $3 \mathrm{mM}, \mathrm{I}_{\text {ovt }} \mathrm{V}$-ramp response slope conductance decreased from $7.38 \pm 1.26 \mathrm{nS}$ to $5.45 \pm 0.94 \mathrm{nS}(n=24, p<0.0001)$ and its reversal potential shifted to a slightly more depolarized value, from $4.78 \pm 0.37 \mathrm{mV}$ to $6.27 \pm 0.71 \mathrm{mV}(p<0.005)$, whereas increasing the $\mathrm{HCO}_{3}{ }^{-}$concentration from 17.5 to $52.5 \mathrm{mM}$ increased the slope conductance from $5.71 \pm$ $0.70 \mathrm{nS}$ to $8.98 \pm 1.37 \mathrm{nS}(n=24, p<0.0001)$ and shifted the reversal potential from $6.40 \pm 0.52 \mathrm{mV}$ to $5.07 \pm 0.33 \mathrm{mV}(p<$ 0.01 ; Figure $6 \mathrm{~F})$. It is clear that results obtained in the tight junctions open condition were similar to those obtained in the usual condition, and therefore we can exclude a role of a tight junction diffusion barrier in our usual experimental condition. Hence, another mechanism must be involved to explain the small changes in $\mathrm{I}_{\mathrm{ovt}} \mathrm{v}$-ramp response reversal potential observed when bath solution anion concentration was modified. It results, probably, from the presence of an unstirred layer inside the membrane and an $\mathrm{I}_{\text {ovt }}$ channels non voltage-dependent basal activity (suggested above) allowing a relative fast transmembrane anionic flux, which, in turn, allows the unstirred layer anionic concentrations to change, rapidly, in parallel with bath solution ion concentration modifications. A similar mechanism to explain similar observations has been proposed by others (Palmer and Frindt 2006) when studying a basolateral $\mathrm{Cl}^{-}$conductance in the isolated cortical collecting duct. For this mechanism to work, and to maintain solutions electrical neutrality, a companion transmembrane cationic flux must occur, probably mediated by the basolateral HCN channels, which exhibit a non voltage-dependent activity (Bolívar et al. 2008).

\section{Is $I_{\text {ovt }}$ mediated by ClC-K channels?}

At this point, we have identified $\mathrm{a} \mathrm{Cl}^{-} / \mathrm{HCO}_{3}{ }^{-}$conductance, and described the main characteristics of its time- and voltage-dependent activation. Now the question to answer is: what type of $\mathrm{Cl}^{-}$channels mediates the $\mathrm{I}_{\text {ovt }}$ current? As mentioned in the introduction, both a CFTR and a $\mathrm{CaC} \mathrm{Cl}^{-}$conductance have been identified in IMCD cells (Husted et al. 1995; Boese et al. 2004). CFTR channels, although permeable to $\mathrm{HCO}_{3}{ }^{-}$(Linsdell et al. 1997; Meyer et al. 2000; Shcheynikov et al. 2004), mediate, in IMCD cells, linear, non-outward rectifying currents, that are not sensitive to external DIDS blockade (Husted et al. 1995; Vandorpe et al. 1995). On the other hand, although $\mathrm{CaC}$ channels mediate, in IMCD cells, outward rectifying currents (Qu et al. 2003; Boese et al. 2004), they are poorly conductive to $\mathrm{HCO}_{3}{ }^{-}$(Qu and Hartzell 2000). Another type of $\mathrm{Cl}^{-}$channels, the $\mathrm{ClC}-\mathrm{K}$ channels (ClC-K1 and $\mathrm{ClC}-\mathrm{K} 2$ ), has been shown to be present in IMCD cells, at least at the mRNA and protein level (Uchida et al. 1993;
Adachi et al. 1994; Vandewalle et al. 1997; Waldegger et al. 2002). Among the two types of ClC-K channels expressed in rat, ClC-K1 channels mediate DIDS-, DPC- and furosemidesensitive outward rectifying currents that resemble the $\mathrm{I}_{\text {ovt }}$ current (Uchida et al 1993, 1995; Uchida and Sasaki 2005). On the other hand, the thin ascending limb of Henle's loop (tALH), a nephron segment expressing $\mathrm{ClC}-\mathrm{K} 1$ channels (Uchida et al. 1995), exhibits a high $\mathrm{HCO}_{3}{ }^{-}$permeability (Flessner and Knepper 1993). Hence, we drive our efforts to test if $\mathrm{I}_{\mathrm{ovt}}$ is mediated by $\mathrm{ClC}-\mathrm{K} 1$ channels. Currents mediated by $\mathrm{ClC}-$ $\mathrm{K}$ channels increase when the external $\mathrm{pH}$ or the external $\mathrm{Ca}^{2+}$ concentration are augmented, and decrease with the opposite changes (Uchida et al. 1995; Waldegger and Jentsch 2000; Waldegger et al. 2002; Mummery et al. 2005). When we decreased the external $\mathrm{pH}$ from 7.4 to 7.1 , the $\mathrm{I}_{\text {ovt }}$ amplitude, during the prepulse to $80 \mathrm{mV}$, decreased from $805.5 \pm 93.0$ pA to $426.0 \pm 61.2 \mathrm{pA}(p<0.0001 ; n=10$; not shown $)$, and the $\mathrm{I}_{\text {ovt }} \mathrm{V}$-ramp response slope conductance decreased from $11.42 \pm 1.26 \mathrm{nS}$ to $6.54 \pm 0.74 \mathrm{nS}(p<0.0001 ; n=10)$; and when we changed the $\mathrm{pH}$ from 7.4 to 7.7 , the $\mathrm{I}_{\text {ovt }}$ amplitude increased from $685.50 \pm 102.6 \mathrm{pA}$ to $1265.5 \pm 193.9 \mathrm{pA}(p<$ $0.0005 ; n=10$; not shown), and the $\mathrm{I}_{\text {ovt }} \mathrm{V}$-ramp response slope conductance increased from $9.89 \pm 1.24 \mathrm{nS}$ to $17.99 \pm 2.47 \mathrm{nS}$ $(p<0.0002 ; n=10)$. This external $\mathrm{pH}$ sensitivity is opposite to that exhibited by CaC channels (Qu and Hartzell 2000). Figure $7 \mathrm{~A}$ illustrates the changes induced by these $\mathrm{pH}$ modifications on the $\mathrm{I}_{\text {ovt }} \mathrm{V}$-ramp response, whereas Figure $7 \mathrm{~B}$ shows the change induced on this response by an increase in the external $\mathrm{Ca}^{2+}$ concentration. When bath solution $\mathrm{Ca}^{2+}$ concentration was raised from $0.5 \mathrm{mM}$ to $2 \mathrm{mM}, \mathrm{I}_{\mathrm{ovt}}$ amplitude increased from $783.7 \pm 17.5 \mathrm{pA}$ to $1211.7 \pm 61.6 \mathrm{pA}(p<0.0001 ; n=12$; not shown); and the $\mathrm{I}_{\text {ovt }} \mathrm{V}$-ramp response slope conductance increased from $9.84 \pm 0.21 \mathrm{nS}$ to $14.73 \pm 0.21 \mathrm{nS}(p<0.0001$; $n=12$ ). These results support our assumption that $\mathrm{I}_{\mathrm{ovt}}$ is a current mediated by $\mathrm{ClC}-\mathrm{K}$ channels.

\section{The anionic conductivity sequence of $I_{\text {ovt }}$}

ClC-K1 and ClC-K2 channels differ in their anions conductivity ratios (Uchida et al. 1993; Adachi et al. 1994; Waldegger and Jentsch 2000). Therefore, we studied the $\mathrm{I}_{\text {ovt }}$ current both in a $\mathrm{Cl}^{-}$rich bath solution $\left(120 \mathrm{mM} \mathrm{Cl}^{-}\right)$and when $112 \mathrm{mM}$ $\mathrm{Cl}^{-}$in this solution was equimolary replaced by $\mathrm{Br}^{-}, \mathrm{I}^{-}$, or $\mathrm{NO}_{3}{ }^{-}$. Figure $7(\mathrm{C}, \mathrm{D}$ and $\mathrm{E})$ shows the currents recorded, in the same cell, respectively in the chloride-rich, the $\mathrm{Br}^{-}$and the $\mathrm{I}^{-}$solution (currents recorded under the $\mathrm{NO}_{3}{ }^{-}$condition are not shown); note that, in comparison with the $\mathrm{Cl}^{-}$control (7C), both $\mathrm{I}_{\text {ovt }}$ currents and $\mathrm{I}_{\text {ovt }}$ tail currents were larger in the $\mathrm{Br}^{-}$condition (7D) and smaller in the $\mathrm{I}^{-}$condition (7E). Figure $7 \mathrm{~F}$ illustrates the $\mathrm{I}_{\text {ovt }} \mathrm{v}$-ramp responses recorded, in the same cell under the four anionic conditions. As measured using the prepulse-ramp voltage protocol, when most $\mathrm{Cl}^{-}$was replaced by $\mathrm{Br}^{-}, \mathrm{I}_{\text {ovt }}$ amplitude increased from 642.3 
$\pm 46.4 \mathrm{pA}$ to $945.5 \pm 46.8 \mathrm{pA}(p<0.0001, n=11$; not shown $)$; the $\mathrm{I}_{\text {ovt }} \mathrm{V}$-ramp response slope conductance increased from $9.83 \pm 0.43 \mathrm{nS}$ to $12.78 \pm 0.52 \mathrm{nS}(p<0.0001 ; n=11)$, and its reversal potential shifted to a slightly less positive value, from $3.68 \pm 0.30 \mathrm{mV}$ to $2.92 \pm 0.56 \mathrm{mV}(p<0.0001)$. On the other hand, when most $\mathrm{Cl}^{-}$was replaced by $\mathrm{I}^{-}, \mathrm{I}_{\text {ovt }}$ amplitude decreased from $755.0 \pm 14.6 \mathrm{pA}$ to $557.0 \pm 7.5 \mathrm{pA}(p<$ $0.0001, n=10$; not shown); the $\mathrm{I}_{\text {ovt }} \mathrm{V}$-ramp response slope conductance decreased from $11.20 \pm 0.19 \mathrm{nS}$ to $8.12 \pm 0.14$ $\mathrm{nS}(p<0.0001 ; n=10)$, and its reversal potential shifted to a slightly more positive value, from $2.22 \pm 0.25 \mathrm{mV}$ to 4.53 $\pm 0.20 \mathrm{mV}(p<0.0001)$; and when most $\mathrm{Cl}^{-}$was replaced by $\mathrm{NO}_{3}{ }^{-}, \mathrm{I}_{\mathrm{ovt}}$ amplitude decreased from $737.2 \pm 109.7 \mathrm{pA}$ to $363.1 \pm 107.4 \mathrm{pA}(p<0.0001, n=10$; not shown $)$; the $\mathrm{I}_{\text {ovt }}$ $\mathrm{v}$-ramp response slope conductance decreased from $11.33 \pm$ $1.57 \mathrm{nS}$ to $6.33 \pm 1.43 \mathrm{nS}(p<0.0001 ; n=10)$, and its reversal potential shifted to a slightly less positive value, from $4.98 \pm$ $0.64 \mathrm{mV}$ to $2.82 \pm 0.21 \mathrm{mV}(p<0.003)$. Then, $\mathrm{I}_{\mathrm{ovt}}$ channels exhibit a $\mathrm{Br}^{-}>\mathrm{Cl}^{-}>\mathrm{I}^{-}>\mathrm{NO}_{3}{ }^{-}$conductivity sequence, which is different from that observed in $\mathrm{ClC}-\mathrm{K} 1$ channels from renal origin $\left(\mathrm{Br}^{-}>\mathrm{NO}_{3}{ }^{-} \geq \mathrm{Cl}^{-}>\mathrm{I}^{-}\right.$, Waldegger and Jentsch $2000)$ or cochlear origin $\left(\mathrm{Br}^{-}=\mathrm{Cl}^{-}>\mathrm{NO}_{3}{ }^{-}>\mathrm{I}^{-}\right.$; Ando and Takeuchi 2000), and is also different from that observed in ClC-K2 channels from renal origin $\left(\mathrm{Br}^{-}>\mathrm{I}^{-}>\mathrm{Cl}^{-}\right.$; Adachi et al. 1994). Hence, our results suggest that $\mathrm{I}_{\text {ovt }}$ is mediated by a no previously described $\mathrm{ClC}-\mathrm{K}$ channel exhibiting a similar conductivity to $\mathrm{Cl}^{-}$than to $\mathrm{HCO}_{3}{ }^{-}$.

\section{Discussion}

This work focuses on the study of a bicarbonate conductance, observed two decades ago, at the basolateral membrane of IMCD cells (Stanton 1989; Imai and Yoshitomi 1990), which was the only anionic current observed either at the basolateral or the apical membrane. In IMCD cells in primary culture, we find a time-dependent outward rectifying anionic current $\left(\mathrm{I}_{\mathrm{ovt}}\right)$, exhibiting a non voltage-dependent component, and which exhibits a similar conductance to $\mathrm{HCO}_{3}{ }^{-}$than to $\mathrm{Cl}^{-}$. Although the voltage and time dependence of $\mathrm{I}_{\mathrm{ovt}}$ resemble that observed in the $\mathrm{CaC}$ currents, previously described in IMCD cell cultures, these $\mathrm{CaC}$ currents are not recorded in the basal condition but require their activation by external ATP, and upon activation, currents decay to the non-activated levels within few minutes (Boese et al. 2000, 2004). We have always recorded $\mathrm{I}_{\text {ovt }}$ in a basal condition, and current recordings may last $1 \mathrm{~h}$ or more. Furthermore, $\mathrm{CaC}$ currents exhibit $\mathrm{I}^{-}>\mathrm{Br}^{-}>\mathrm{Cl}^{-}$conductivity sequence (Boese et al. 2000), and an external $\mathrm{pH}$ sensitivity opposite to that observed in $\mathrm{I}_{\text {ovt }}$ (Qu and Hartzell 2000). Hence, $\mathrm{I}_{\text {ovt }}$ may not be mediated by $\mathrm{CaC}$ channels. $\mathrm{I}_{\mathrm{ovt}}$ may also not be mediated by CFTR, previously described in cultured IMCD cells, because CFTR currents are time and voltage independent, and exhibit a I' $>\mathrm{Br}^{-}>\mathrm{Cl}^{-}$conductivity sequence (Husted et al. 1995; Vandorpe et al. 1995). On the other hand, while the voltage dependence, time course, as well as the external $\mathrm{pH}, \mathrm{Ca}^{2+}$, DIDS, DPC and furosemide sensitivity of $\mathrm{I}_{\mathrm{ovt}}$ resemble those of the currents mediated by ClC-K1 channels (Uchida et al. 1993, 1995; Waldegger and Jentsch 2000; Uchida and Sasaki 2005), $\mathrm{I}_{\text {ovt }}$ differs from ClC-K1 currents in its $\mathrm{Br}^{-}>\mathrm{Cl}^{-}>\mathrm{I}^{-}>\mathrm{NO}_{3}^{-}$conductivity sequence. However, based on its external $\mathrm{pH}$ and $\mathrm{Ca}^{2+}$ sensitivity, we propose that $\mathrm{I}_{\text {ovt }}$ may be mediated by a not previously described $\mathrm{ClC}-\mathrm{K}$ channel. This proposal is supported by the high degree of homology $(>80 \%)$ existing between the four most studied types of ClC-K channels (ClC-K1, and - K2, from rat, and -Ka and -Kb, from human; Uchida and Sasaki 2005), and by several studies reporting the expression of a ClC-K gene in the rat IMCD cells. Among these studies there are RT-PCR assays reporting the presence of a $\mathrm{ClC}-\mathrm{K} 1$ transcript (Uchida et al. 1993; Vandewalle et al. 1997; Waldegger et al. 2002), and of a ClC-K2 transcript (Adachi et al. 1994; Vandewalle et al. 1997), though one of such assays did not observe a ClC-K2 transcript (Waldegger et al. 2002). Furthermore, among three immunocytochemistry studies using a $\mathrm{ClC}-\mathrm{K}$ antibody, which don't discriminate between $\mathrm{ClC}-\mathrm{K} 1$ and $\mathrm{K} 2$ proteins, one study observed a $\mathrm{ClC}-\mathrm{K}$ immunoreactivity in IMCD cells (Vandewalle et al. 1997), but this reactivity was not observed by the two others (Mejia and Wade 2002; Pannabecker et al. 2004). These previous results allows us to postulate, with a reasonable certainty, that IMCD cells express a $\mathrm{ClC}-\mathrm{K}$ channel protein, which identity remains to be determined, and which probably mediates the $\mathrm{I}_{\text {ovt }}$ current we observed.

Is the $\mathrm{I}_{\text {ovt }}$ conductance the basolateral bicarbonate conductance previously observed in the isolated and perfused rat IMCD (Stanton 1989)? Although the several minutes delay observed until blocking agents attained their maximal inhibitory effect on $\mathrm{I}_{\text {ovt }}$ may be suggestive of a basolateral localization of $\mathrm{I}_{\text {ovt }}$ channels, this observation is not sufficient to confirm this localization. However, a basolateral $\mathrm{I}_{\text {ovt }}$ conductance, exhibiting an instantaneous, non voltagedependent activity, may explain the basolateral membrane depolarization observed, in that previous study, when the external $\mathrm{pH}$ and bicarbonate concentration were simultaneously decreased, and may also explain the inhibition of this depolarization by DIDS; the absence of a similar depolarization when the external chloride concentration was decreased, would, however, not be compatible with such an explanation.

If $\mathrm{I}_{\text {ovt }}$ is a basolateral membrane conductance with a non voltage-dependent activity, what physiological role may it perform? The IMCD of the rat is a major site of urinary acidification (Bengele et al. 1986), this is accomplished by an apical active $\mathrm{H}^{+}$secretion and by a basolateral passive $\mathrm{Na}^{+}$-independent bicarbonate reabsorption, which may be 
blocked by disulfonic stilbenes (like DIDS and 4-acetamido4'-isothiocyanatostilbene-2,2'-disulfonic acid (SITS) (Ulrich and Papavassiliou 1981; Praetorious et al. 2004). The $\mathrm{I}_{\mathrm{ovt}}$ channels, as a DIDS-sensitive basolateral $\mathrm{HCO}_{3}{ }^{-}$conductive pathway may probably participate in this bicarbonate reabsorption. Another probable physiological role of $\mathrm{I}_{\mathrm{ovt}}$ channels has been suggested by us in a previous report (Bolívar et al. 2008). When the kidney acutely passes from a diuresis state to an antidiuresis state (during the early phase of the antidiuretic state) the $\mathrm{Na}^{+}$and $\mathrm{Cl}^{-}$transport activity of the $\mathrm{tALH}$ provides the basis for an early increment in inner medullary interstitial $\mathrm{Na}^{+}$and $\mathrm{Cl}^{-}$concentration (Knepper et al. 2003; Fenton and Knepper 2007; Layton et al. 2009), and, thereafter, the IMCD cells become exposed to a slowly increasing interstitial hypertonicity. In this condition, an influx of $\mathrm{Na}^{+}$(mediated by HCN channels; Bolívar et al. 2008) and $\mathrm{Cl}^{-} / \mathrm{HCO}_{3}^{-}$(mediated by $\mathrm{I}_{\mathrm{ovt}}$ channels) through the basolateral membrane of IMCD may probably allow a rapid cell-interstitium osmotic equilibration, contributing to endow the IMCD cells with the necessary osmotic force for water reabsorption. Hence, the $\mathrm{I}_{\text {ovt }}$ conductance may probably participate in the IMCD urine concentrating mechanism.

Acknowledgments. We thank Dr. Dieter Mascher for critical reviewing of the manuscript. This work was partially supported by SEP-CONACyT, Grant CB-2007/83356, and by DGAPA, UNAM, Grants IN206609 and IN214312 to Dr. Juan J. Bolívar.

\section{References}

Adachi S., Uchida S., Ito H., Hata M., Hiroe M., Marumo F., Sasaki S. (1994): Two isoforms of a chloride channel predominantly expressed in thick ascending limb of Henle's loop and collecting ducts of rat kidney. J. Biol. Chem. 269, 17677-17683

Ando M., Takeuchi S. (2000): mRNA encoding ,ClC-K1, a kidney $\mathrm{Cl}^{-}$channel' is expressed in marginal cells of the stria vascularis of rat cochlea: its possible contribution to $\mathrm{Cl}^{-}$currents. Neurosci. Lett. 284, 171-174 http://dx.doi.org/10.1016/S0304-3940(00)01021-1

Bengele H. H., Schwartz J. H., McNamara E. R., Alexander E. A. (1986): Chronic metabolic acidosis augments acidification along the inner medullary collecting duct. Am. J. Physiol. Renal Physiol. 250, F690-694

Boese S. H., Glanville M., Aziz O., Gray M. A., Simmons N. L. (2000): $\mathrm{Ca}^{2+}$ and cAMPactivated $\mathrm{Cl}^{-}$conductances mediate $\mathrm{Cl}^{-}$secretion in a mouse renal inner medullary collecting duct cell line. J. Physiol. 523, 325-338 http://dx.doi.org/10.1111/j.1469-7793.2000.t01-1-00325.x

Boese S. H., Aziz O., Simmons N. L., Gray M. A. (2004): Kinetics and regulation of a $\mathrm{Ca}^{2+}$-activated $\mathrm{Cl}^{-}$conductance in mouse renal inner medullary collecting duct cells. Am. J. Physol. Renal Physiol. 286, F682-692

http://dx.doi.org/10.1152/ajprenal.00123.2003
Bolívar J. J., Cereijido M. (1987): Voltage and $\mathrm{Ca}^{2+}$-activated $\mathrm{K}^{+}$ channel in cultured epithelial cells (MDCK). J. Membrane Biol. 97, 43-51 http://dx.doi.org/10.1007/BF01869613

Bolívar J. J, Tapia D., Arenas G., Castañón-Arreola M., Torres H., Galarraga E. (2008): A Hyperpolarization-activated, cyclic nucleotide-gated, (Ih-like) cationic current and HCN genes expression in renal inner medullary collecting duct cells. Am. J. Physiol. Cell Physiol. 294, C893-906

Cereijido M., Meza I., Martínez-Palomo A. (1981): Occluding junctions in cultured epithelial monolayers. Am. J. Physiol. Cell Physiol. 240, C96-102

Contreras R. G., Avila G., Gutierez C., Bolívar J. J., González-Mariscal L., Darzon A., Beaty G., Rodriguez-Boulan E., Cereijido M. (1989): Repolarization of $\mathrm{Na}^{+}-\mathrm{K}^{+}$pumps during stablishment of epithelial monolayers. Am. J. Physiol. Cell Physiol. 257, C896-905

Escobar L. I., Martínez-Téllez J. C., Salas M., Castilla S. A., Carrisoza R., Tapia D., Vázquez M., Bargas J., Bolívar J. J. (2004): A voltage-gated $\mathrm{K}^{+}$current in renal inner medullary collecting duct cells. Am. J. Physiol. Cell Physiol. 286, C965-974 http://dx.doi.org/10.1152/ajpcell.00074.2003

Evans M. G., Marty A., Tan Y.P., Trautmann A. (1986): Blockage of $\mathrm{Ca}$-activated $\mathrm{Cl}$ conductance by furosemide in rat lacrimal glands. Pflügers Arch. 406, 65-68 http://dx.doi.org/10.1007/BF00582955

Fenton R. A., Knepper M. A. (2007): Mouse models and the urinary concentration mechanism in the new millennium. Physiol. Rev. 87, 1083-1112 http://dx.doi.org/10.1152/physrev.00053.2006

Flessner M. F., Knepper M. A. (1993): Ammonium and bicarbonate transport in isolated perfused rodent ascending limbs of the loop of Henle. Am. J. Physiol. Renal Physiol. 264, F837-844

Gonzalez-Mariscal L., Contreras R. G., Bolívar J. J., Ponce A., Chávez de Ramirez B., Cereijido M. (1990): Role of calcium in tight junctions formation between epithelial cells. Am. J. Physiol. Cell Physiol. 259, C978-986

Husted R. F., Volk K. A., Sigmund R. D., Stokes J. B. (1995): Anion secretion by the inner medullary collecting duct. Evidence for involvement of the cystic fibrosis transmembrane conductance regulator. J. Clin. Invest. 95, 644-650 http://dx.doi.org/10.1172/JCI117709

Illek B., Yankaskas J. R., Mathen T. E. (1997): cAMP and genistein stimulate $\mathrm{HCO}_{3}{ }^{-}$, conductance through CFTR in human airway epithelia. Am. J. Physiol. Lung Cell. Mol. Physiol. 272, L752-761

Imai M., Yoshitomi K. (1990): Electrophysiological study of inner medullary collecting duct of hamsters. Pflügers Arch. 416, $180-188$ http://dx.doi.org/10.1007/BF00370240

Ishiguro H., Steward M. C., Naruse S., Ko S. B. H., Goto H., Case R. M., Kondo T., Yamamoto A. (2009): CFTR functions as a bicarbonate channel in pancreatic duct cells. J. Gen. Physiol. $133,315-326$ http://dx.doi.org/10.1085/jgp.200810122

Jentsch T. J., Stein V., Weinreich F., Zdebik A. A. (2002): Molecular structure and physiological function of chloride channels. Physiol. Rev. 82, 503-568 
Kibble J. D., Trezise A. E. O., Brown P. D. (1996): Properties of the cAMP-activated $\mathrm{Cl}^{-}$current in choroid plexus epithelial cells isolated from the rat. J. Physiol. 496, 69-80

Knepper M. A., Saidel G. M., Hascall V. C., Dwyer T. (2003): Concentration of solutes in the renal inner medulla: interstitial hyaluronan as a mechano-osmotic transducer. Am. J. Physiol. Renal Physiol. 284, F433-446

Layton A. T., Layton H. E., Dantzler W. H., Pannabecker T. L. (2009): The mammalian urine concentrating mechanism: hypotheses and uncertainties. Physiology 24, 250-256 http://dx.doi.org/10.1152/physiol.00013.2009

Linsdell P., Tabcharani J. A., Rommens J. M., Hou Y. X., Chang X. B., Tsui L. C., Riordan J. R., Hanrahan J. W. (1997): Permeability of wild-type and mutant cystic fibrosis transmembrane conductance regulator chloride channels to polyatomic anions. J. Gen. Physiol. 110, 355-364 http://dx.doi.org/10.1085/jgp.110.4.355

Martínez-Palomo A., Meza I., Beaty G., Cereijido M. (1980): Experimental modulation of occluding junctions in a cultured transporting epithelium. J. Cell Biol. 87, 736-745 http://dx.doi.org/10.1083/jcb.87.3.736

Mejia R., Wade J. N. (2002): Immunomorphometric study of rat renal inner medulla. Am. J. Physiol. Renal Physiol. 282, F553-557

Meyer G., Garavaglia M. L., Bazzini C., Botta G. (2000): An anion channel in guinea pig gallbladder epithelial cells is highly permeable to $\mathrm{HCO}_{3}^{-}$. Biochem. Biophys. Res. Comm. 276, 312-320

http://dx.doi.org/10.1006/bbrc.2000.3400

Moreno J., Cruz-Vera L. R., García-Villegas M. R., Cereijido M. (2002): Polarized expression of shaker channels in epithelial cells. J. Membrane Biol. 190, 175-187 http://dx.doi.org/10.1007/s00232-002-1034-4

Moser A. J., Gangopadhyay A., Bradbury N. A., Peters K. W., Frizzell R. A., Bridges R. J. (2007): Electrogenic bicarbonate secretion by prairie dog gallbladder. Am. J. Physiol. Gastrointest. Liver Physiol. 292, G1683-1694

http://dx.doi.org/10.1152/ajpgi.00268.2006

Mummery J. L., Killey J., Linsdell P. (2005): Expression of the chloride channel ClC-K in human airway epithelial cells. Can. J. Physiol. Pharmacol. 83, 1123-1128 http://dx.doi.org/10.1139/y05-112

Padilla-Benavidez T., Roldán M. L., Larre I., Flores-Benitez D., Villegas-Sepúlveda N., Contreras R. G., Cereijido M., Shoshani L. (2010): The polarized distribution of $\mathrm{Na}^{+}, \mathrm{K}^{+}$-ATPase: role of the interaction between $\beta$ subunits. Mol. Biol. Cell. 21, 2217-2225 http://dx.doi.org/10.1091/mbc.E10-01-0081

Palmer L. G., Frindt G. (2006): $\mathrm{Cl}^{-}$channels of the distal nephron. Am. J. Physiol. Renal Physiol. 291, F1157-1168 http://dx.doi.org/10.1152/ajprenal.00496.2005

Pannabecker T. L., Abbot D. E., Danzler W. H. (2004): Threedimensional functional reconstruction of inner medullary thin limbs of Henle's loop. Am. J. Physiol. Renal Physiol. 286, F38-45 http://dx.doi.org/10.1152/ajprenal.00285.2003

Praetorius J., Kim Y. H., Bouzinova E. V., Frische S., Rojek A., Aalkjær C., Nielsen S. (2004): NBCn1 is a basolateral $\mathrm{Na}^{+}-$
$\mathrm{HCO}_{3}{ }^{-}$cotransporter in rat kidney inner medullary collecting ducts. Am. J. Physiol. Renal Physiol. 286, F903-912 http://dx.doi.org/10.1152/ajprenal.00437.2002

Qu Z., Hartzell H. C. (2000): Anion permeation in $\mathrm{Ca}^{2+}$-activated $\mathrm{Cl}^{-}$channels. J. Gen. Physiol. 116, 825-844 http://dx.doi.org/10.1085/jgp.116.6.825

Qu Z., Wei R. W., Hartzell H. C. (2003): Characterization of $\mathrm{Ca}^{2+}$-activated $\mathrm{Cl}^{-}$currents in mouse kidney inner medullary collecting duct cells. Am. J. Physiol. Renal Physiol. 285, F326-335

Shcheynikov N., Kim K. H., Kim K., Dorwart M. R., Ko S. B. H., Goto H., Naruse S., Thomas P. J., Muallem S. (2004): Dynamic control of cystic fibrosis transmembrane conductance regulator $\mathrm{Cl}^{-} / \mathrm{HCO}_{3}{ }^{-}$selectivity by external $\mathrm{Cl}^{-}$. J. Biol. Chem. 279, 21857-21865 http://dx.doi.org/10.1074/jbc.M313323200

Schultz B. D., Singh A. K., Devor D. C., Bridges R. J. (1999): Pharmacology of CFTR chloride channel activity. Physiol. Rev. (Supp1.) 79, S109-144

Stanton B. (1989): Characterization of apical and basolateral membrane conductances of rat inner medullary collecting duct. Am. J. Physiol. Renal Physiol. 256, F862-868

Uchida S., Sasaki S., Furukawa T., Hiraoka M., Imai T., Hirata Y., Marumo F. (1993): Molecular cloning of a chloride channel that is regulated by dehydration and expressed predominantly in kidney medulla. J. Biol. Chem. 268, 3821-3824

Uchida S., Sasaki S., Nitta K., Uchida K., Horita S., Nihei H., Marumo F. (1995): Localization and functional characterization of rat kidney-specific chloride channel, ClC-K1. J. Clin. Invest. 95, 104-113 http://dx.doi.org/10.1172/JCI117626

Uchida S., Sasaki S. (2005): Function of chloride channels in the kidney. Annu. Rev. Physiol. 67, 759-778 http://dx.doi.org/10.1146/annurev.physiol.67.032003.153547

Ullrich K. J., Papavassiliou F. (1981): Bicarbonate reabsorption in the papillary collecting duct of rats. Pflügers Arch. 389, 271-275 http://dx.doi.org/10.1007/BF00584789

Vandewalle A., Cluzeaud F., Bens M., Kieferle S., Steinmeyer K., Jentsch T. J. (1997): Localization and induction by dehydration of ClC-K chloride channels in the rat kidney. Am. J. Physiol. Renal Physiol. 272, F678-688

Vandorpe D., Kizer N., Ciampollilo F., Moyer B., Karlson K., Guggino W. B., Stanton B. A. (1995): CFTR mediates electrogenic chloride secretion in mouse inner medullary collecting duct (mIMCDK2) cells. Am. J. Physiol. Cell Physiol. 269, C683-689

Waldegger S., Jentsch T. J. (2000): Functional and structural analysis of $\mathrm{ClC}-\mathrm{K}$ chloride channels involved in renal disease. J. Biol. Chem. 275, 24527-24533 http://dx.doi.org/10.1074/jbc.M001987200

Waldegger S., Jeck N., Barth P., Peters M., Vitzthum H., Wolff K., Kurtz A., Konrad M., Seyberth H. W. (2002): Barttin increases surface expression and change current properties of $\mathrm{ClC}-\mathrm{K}$ channels. Pflügers Arch. 444, 411-418 http://dx.doi.org/10.1007/s00424-002-0819-8

Received: October 15, 2013

Final version accepted: February 6, 2014 